\title{
Demand Aggregation as a Strategy for Untapping Buildings' Energy Renovation Potential: Diagnosis and Prioritization Methodology and Case Study from the Basque Country
}

\author{
Olatz Nicolas *(D) and Patricia Molina-Costa (D) \\ TECNALIA, Basque Research and Technology Alliance (BRTA), Bizkaiko Teknologia Parkea, Astondo Bidea, \\ 700 Eraikina, E-48160 Derio, Spain; patricia.molina@tecnalia.com \\ * Correspondence: olatz.nicolas@tecnalia.com; Tel.: +34-667-178861
}

check for updates

Citation: Nicolas, O.; Molina-Costa, P. Demand Aggregation as a Strategy for Untapping Buildings' Energy

Renovation Potential: Diagnosis and Prioritization Methodology and Case Study from the Basque Country. Sustainability 2021, 13, 13881. https://doi.org/10.3390/su132413881

Academic Editors: Iker González Pino and Jon Terés-Zubiaga

Received: 15 October 2021

Accepted: 9 December 2021

Published: 15 December 2021

Publisher's Note: MDPI stays neutral with regard to jurisdictional claims in published maps and institutional affiliations.

Copyright: (c) 2021 by the authors. Licensee MDPI, Basel, Switzerland. This article is an open access article distributed under the terms and conditions of the Creative Commons Attribution (CC BY) license (https:// creativecommons.org/licenses/by/ $4.0 /)$.

\begin{abstract}
Energy renovation of post-World War II private multifamily residential buildings has been identified to have a great deal of energy-saving potential but faces a great challenge across Europe, and especially in South Europe, due to fragmented property structures and longer return periods in energy efficiency investments. However, there is great deal of potential in activating demand aggregation in areas with homogeneous typologies. Local authorities play a key role in leading district-scale renovation but lack adequate methods for analysing and prioritizing areas from an integrated perspective, including social aspects. The methodology presented in this paper aims to support local authorities by providing a tool for the diagnosis and prioritization of homogeneous groups of residential buildings to address their renovation based on an analysis of their needs and opportunity factors. First, the methodology sets the universe of analysis; second, based on indicators, it provides comparative information within the municipality, which leads to a prioritization of areas for building renovations according to the state of the building and to the socio-economic profile of the residents; lastly, a detailed diagnosis of selected groups is performed, providing information to design the Renovation Action Plans accordingly. The application of the methodology in Basauri is presented in this paper.
\end{abstract}

Keywords: building renovation; housing; demand aggregation; methodology; Basque Country

\section{Introduction}

\subsection{The Challenge}

The building sector is responsible for approximately $36 \%$ of GHG emissions and $40 \%$ of the energy consumption in Europe. Two thirds (65\%) of the European building stock was built before 1980, and about $97 \%$ of the E.U.'s buildings must be upgraded to achieve the 2050 decarbonization goal; however, only $0.4 \%-1.2 \%$ are renovated each year $[1,2]$. Building renovation offers multiple benefits and high social and private returns across several dimensions, especially in the residential sector. Apart from energy efficiency, it enhances climate resilience, circularity, and renewables uptake, improves indoor air quality and health, and lowers poverty. Moreover, it is a labour-intensive activity, with a high percentage of SMEs, that can make a key contribution to creating jobs and stimulating economic recovery in the context of the COVID-19 pandemic.

Despite more than a decade of energy renovation policies for buildings in the European Union, in many countries this sector has not yet achieved its full potential; thus, the established goal of a decarbonized building stock by 2050 seems still unachievable in many cases. Moreover, despite the relatively high and rising energy costs in Europe and the vast array of technology and service options available, the energy-efficient buildings market is under-delivering on the cost-effective and technically feasible improvement opportunities available to consumers [3,4]. In the context of the new European Green Deal, the EC is pushing for a 'renovation wave' in Europe [5], further prioritized under the recovery plan 
for the European Union, aimed at increasing the rate and quality of the renovation of existing buildings and, thereby, helping to decarbonize the building stock. The 'Renovation wave" initiative will build on measures agreed to under the "Clean Energy for all Europeans" package, notably the requirement for each E.U. country to develop Long-Term Renovation Strategies (LTRSs). As defined by Article 4 of the Energy Efficiency Directive (2012, amended by DEE 2018/2002 and further defined under the amended Energy Performance of Buildings Directive (EU)2018/844), Member States developed in 2014 their Long-Term Renovation Strategies (LTRSs), which were revised in 2017 and 2020, where they set ambitious renovation goals at the national level. Despite the valuable strategic effort, implementation has not followed in most countries. According to the results of the H2020 project BUILD UPON2 [6], the main challenges for LTRS implementation include a lack of mechanisms to ensure consultation and cooperation between local authorities and the national government on building renovation policy; a lack of communication channels to organize this cooperation; a lack of capacity of local authorities to take on the responsibility of implementing the renovation strategy, and a lack of both the financial resources and the qualified staff to execute and implement renovation policies and measures; and insufficient awareness about the multiple benefits of building renovation.

Barriers to building renovation include structural barriers, such as those linked to the characteristics of the building stock (the long lifetimes of buildings, limited industrialization, regional climatic differences hampering standardized approaches); information barriers (a lack of awareness of its benefits, insufficient knowledge about the building stock); market failures, such as housing values not always reflecting the buildings' energy performance, split incentives between owners and tenants, immature business models for energy performance in the renovation, and the non-monetary nature of some benefits of renovation; a lack of expertise and an insufficient workforce; a scattered demand, with project aggregation and district-scale renovation still being challenges; and regulatory barriers, such as complex permit procedures [7].

In particular, the renovation of the residential sector is the most challenging problem to tackle, as most of it is privately owned, and therefore the investment is scattered and depends on private budgets. Investment is even more complex in privately owned multifamily apartment buildings where several owners need to agree to start a renovation and have difficulties accessing the necessary financing [8]. In addition, the COVID-19 crisis has sharpened the need to secure comfortable, energy-efficient housing for all.

Moreover, there is strong evidence that approaching the renovation of residential buildings on a one-by-one basis is less effective than doing it on a district scale $[9,10]$, especially when neighbourhoods were built as part of a homogeneous plan and with similar building typologies. In particular, the benefits of addressing renovation at the district scale as a key strategy to reduce $\mathrm{CO}_{2}$ emissions have been widely analysed [11,12]. However, the benefits go beyond the energy dimension, since similar buildings' needs, due to building typology homogeneity, such as accessibility issues, as well as similar social characteristics, are also key to benefiting from the lower costs thanks to economies of scale and to design an adequate response to similar social needs.

Throughout Europe, a large number of buildings were built as part of large estates (groups of almost identical buildings) after World War II with poor construction materials and without proper insulation measures or lifts, featuring similar refurbishment needs. Although the situation differs across countries, featuring different ownership structures, in South Europe multi-ownership is more commonly distributed [8]. For example, this typology accounts for $14 \%$ of the residential building stock in Spain (it accounts for 2,538,170 dwellings) (the number of dwellings in multi-storey multifamily buildings built between 1940 and 1980 and without a lift (Source: INE, 2011)). Thus, it would be more cost-effective to aggregate demand and renovate them simultaneously than on an individual basis, taking advantage of economies of scale. However, demand aggregation implies greater complexity, especially in countries such as Spain where this type of building is usu- 
ally co-owned by apartment owners (in condominium property structures), and therefore renovation requires multiple property owners to reach agreements [13].

In addition, in the moderate climate areas of the South of Europe, where this typology abounds, energy savings are not perceived as a priority and thus do not act as drivers for building renovation [4]. Therefore, it is key to foster an integrated approach to renovation that includes not only energy efficiency but also improved accessibility and habitability and to demonstrate and effectively communicate the benefits of energy renovation in relation to the quality of life of inhabitants, beyond the economic savings in the energy bill.

From a social perspective, apart from the management complexities of multi-owner buildings, the renovation of these buildings faces the particular barrier of their being typically inhabited by aging residents who have remained in place, as well as low- and medium-income residents, who may lack sufficient motivation as well as the financial and organizational capacities to cover refurbishment investments. Therefore, proper governance, communication, and management are key to boosting the renovation of these buildings.

District-level renovations call for strong leadership and collaborative work among stakeholders; in this context, local public bodies, as well as their affiliated housing agencies, can play a key role $[12,14]$. Local public authorities are usually charged with the implementation of policies that have been designed at higher levels of public administration. For instance, national policies and subsidies for energy efficiency and building renovation are designed at the national level, not being connected with a local territory, and therefore not having a detailed knowledge of the barriers that such policies face on the ground. For instance, local authorities must approve renovation projects for each building, work with residents in case they can benefit from public funding or tax benefits for renovating their buildings, etc. They usually have a clear vision of the barriers and opportunities for such policies in their territories but are rarely truly involved in policy design.

Many studies have focused on developing methodologies for residential building stock analysis from the energy demand and performance perspective and the need to localize and characterize the most inefficient urban clusters (e.g., [15-17]). However, case studies have confirmed the importance of social factors to achieving district renovations [12], highlighting the relationship between residential energy and social characteristics in policymaking [18]. Moreover, drivers for building renovation are not necessarily restricted to energy benefits and include wider quality of life aspects such as accessibility and indoor environment improvements [12]. The lack of adequate knowledge about the building stock and its inhabitants is one of the main barriers hampering local authorities' capacity to foster renovations. In particular, analysing urban vulnerability at the intra-urban level possesses several challenges in terms of data sources that ask for methodological innovation [19].

Studies on urban vulnerability abound, starting from the OCDE report from 1998 [20]. In Spain, this work inspired the first analysis of vulnerable areas based on the 1991 Population and Housing Census, which was updated in 2001 and 2011 [21] and offers a GIS-based tool for consulting the results at the census tract level for all Spanish municipalities. Later, a catalogue of vulnerable neighbourhoods was developed with a more detailed analysis of vulnerability in capital cities and cities with more than 50,000 inhabitants [22]. In addition, a specific Atlas of Residential Buildings was developed [23] by the Spanish Government with data from the 2001 and 2011 Censuses. These works have been the basis on which local governments have identified vulnerable areas in their municipalities. However, the lack of actualized data has hindered its usefulness in more recent attempts to design operative policies to foster building renovation from a multidimensional perspective. More recently, the 2020 edition of the LTRS for Spain [24] has provided a very interesting aggregated analysis of the energy performance of the Spanish residential building stock; however, the lack of information at the municipal and census tract levels has hindered its potential to guide local-level strategies [25]. It actually includes a recommendation addressed to regional and local authorities to develop their own analysis and renovation strategies 
(Measure 1.4 of Axis 1 of the Implementation of proposed measures in the 2020 LTRS for Spain).

At the regional level, the Basque Country was a pioneer in 2011 by developing its own analysis of the renovation needs of the housing stock at the census tract level [26], including six dimensions in the analysis: social vulnerability, building habitability, accessibility, stability, energy efficiency, and density of dwellings per census tract. Other regional governments followed with similar analyses, which were the basis for their regional urban regeneration strategies, e.g., Castilla y León [27] and the Comunitat Valenciana [28]. At the local level, Zaragoza was a pioneer in 2004 with studies and proposals for the renovation of 21 areas of interest [29]. More recently, several municipalities have analyzed vulnerable areas to help guide their building renovation strategies (i.e., Barcelona [30], Madrid [31], Palencia [32], and Sestao [33]). Each of them has taken a different approach regarding indicators and the scale of analysis, with the majority working at the census tract level.

Despite this vast array of experiences, there is still not a systematic approach to the diagnosis and prioritization of building renovation areas from a multidimensional perspective, which includes not only energy-related aspects but also other drivers for renovation, such as accessibility needs, as well as a social characterization. In addition, most of the analysed methodologies rely on a broad set of indicators, some of which are not easily updated. Moreover, the analysis at the census tract level hinders the understanding of building typologies, which, as explained above, bring the potential of demand aggregation to the renovation equation. Identification of homogeneous groups of residential estates would provide a very valuable input to municipalities to identify their needs and opportunities and to guide public investments.

\subsection{The Case of the Basque Country and the AGREE Project Approach}

This approach is the basis of the AGREE project "Aggregation and improved Governance for untapping Residential Energy Efficiency potential in the Basque Country" (H2020 GA 847068), whose overall objective is to trigger investments in energy-efficient retrofitting of private multifamily residential building estates in the Basque Country through the development and deployment of innovative mechanisms for demand activation and aggregation, improved governance, and tailored financing solutions. It includes the development of a replicable methodology for the characterization and integrated diagnosis of building estates that allows for the prioritization of and interventions that are more tailored to the target building group typology and its residents' social profile. The AGREE project involves three municipalities located in the Basque Country in which this methodology was applied: Basauri, Donostia-San Sebastian, and Vitoria-Gasteiz.

Due to the large amount of constructive expansion that developed around the industrial activity in the Basque Country, especially after the end of the Spanish Civil War, its residential building stock is very old compared with the Spanish average [34]: 47\% of the residential dwellings in the Basque Country were built before the 1960s; 15\% before the 1950s; and 32\% between 1950 and 1960. However, the largest amount of urban growth took place between 1950 and 1960, followed by a developmental phase between 1960 and 1980 . This trend ended in the 1980s with the arrival of the economic crisis, coinciding with the arrival of the first thermal regulation in Spain (Norma Básica de la Edificación, NBE-CT-79, sobre Condiciones Térmicas en los edificios). These buildings' typology is independent blocks adapted to the orography with inter-block open spaces that shape homogeneous complexes of variable sizes. Initially, they were located on the outskirts of the cities and did not have the necessary facilities; however, due to urban growth, they have been integrated into the urban fabric [35]. These buildings are usually co-owned by dwelling owners in condominium property structures, and they are inhabited by their original dwellers, now an aging population, as well as low- and medium-income residents who have located to these buildings due to their lower rent prices.

According to the study "Diagnosis of the renovation needs of the residential building stock in the Basque Country" [26], buildings of the post-war period, built by public bodies, 
industrial companies, and work cooperatives in response to the urgent need for housing for workers who immigrated to the Basque Country, feature poor-quality materials, lack the thermal conditions required for a comfortable home, and thus are large energy consumers. A total of $90 \%$ of the existing buildings have an energy consumption rating that is lower than $\mathrm{D}$ according to energy performance certificates. Moreover, most of these buildings $(55 \%)$ have more than four floors and do not have a lift.

As in many areas of the South of Europe, the Basque Country has a moderate climate; therefore, energy saving is not perceived as an economic benefit and does not act as a driver for building renovation. On the other hand, there are other priorities, such as improvement of accessibility and habitability. Hence, it is key to foster an integrated approach to renovation that includes not only energy efficiency but improvement of the quality of life of inhabitants as a whole.

\subsection{Objective and Structure}

This paper describes the methodology developed in AGREE based on GIS-based multi-criteria decision analysis (GIS-MCDA). This new methodology aims to systematize the identification, analysis, and prioritization of residential renovation areas while fostering demand aggregation. It is based on a realistic and applied approach that includes the selection of fewer, but relevant, indicators, as well as the identification of data sources that are available for all municipalities in the Basque Country, which simplifies its application. The indicators were selected to inform the design of specific policies; in particular, the Integrated Renovation Action Plans that may serve as pilots in the municipalities.

The methodology is based on a comparative analysis within the municipality, which leads to a prioritization of areas for building renovation according to the state of the building and the economic and demographic profile of the residents.

This paper is organized as follows. Section 2 describes the methodology proposed. Section 3 presents the results of its application in the case of Basauri. Finally, Section 4 presents a discussion of and our conclusions on the challenges and opportunities of applying this methodology.

\section{Methodology}

This methodology builds on previous work conducted by Tecnalia at the regional level in the Basque Country in 2012 [26] and the municipal level in 2014 [33], which was further refined and systematized in 2018 [34]. The first study consisted of a multidimensional analysis of residential vulnerability at the census tract level using data from the 2001 Census, and it included the whole territory of the Basque Country, while the second study was developed for the municipality of Sestao to support the identification of building clusters and prioritization of building groups for renovation actions.

It follows a three-step approach: (1) definition of the universe of analysis; (2) selection of areas based on indicators at the census tract level; and (3) detailed diagnosis of selected groups on the building scale.

\subsection{Stage 1: Definition of the Universe of Analysis}

The first step of the methodology deals with identifying the representative sample or universe to be analysed. This helps to focus and limit the study in alignment with policy objectives. The scope of the AGREE project is homogeneous sets of multifamily residential buildings with three or more floors built between 1940 and 1970, before the thermal regulation NBE-CT-79 came into force, and thus their refurbishment offers a great deal of energy saving potential.

A GIS-based spatial analysis was used for the Multi-Criteria Decision Analysis (MCDA) method. To visually delimit (in .shp, shape format) these buildings, the cartography of buildings in each of the municipalities was obtained from public sources such as the Basque Institute of Statistics (EUSTAT), which provides a system for locating postal addresses in a georeferenced way through NORA codes and the Cadastre. Territorial 
databases are unified this way and are the starting point for creating the databases for each pilot case, in which detailed information was added, such as the year of construction, the number of floors, the number of dwellings, and use.

Based on this cartography, homogeneous sets of multifamily residential buildings with three or more floors built between 1940 and 1970 in the three municipalities were delimited and contrasted with those areas delimited according to specific municipal planning instruments of each municipality.

In Basauri, the pre-selected areas were those that the Land Use Plan of Basauri (PGOU) identified as Areas of Integral Renovation (ARIs); in Vitoria-Gasteiz, nine areas were preselected according to the socio-urban studies performed in the framework of the Strategic Plan of Vitoria-Gasteiz 2015-2019; and in Donostia, the pre-selected areas correspond to those whose accessibility needs improving according to the Municipal Housing Plan.

\subsection{Stage 2: Prioritization and Selection Based on Indicators}

This step aims to provide municipalities with a tool on which to base decisions for their municipal renovation policies. It provides a prioritization of the areas based on demand aggregation potential due to the buildings' homogeneity, the lack of accessibility, and a specific socio-economic profile of the population.

The selection of intervention areas is carried out through analysis on the census section scale regarding two fields: (1) the level of renovation need, according to the state of the building; and (2) its priority, according to the economic profile of the residents. Based on previous work, seven indicators relevant to these two fields were identified, and each criterion was created as a map layer in the GIS project.

\subsubsection{Building Indicators}

The following indicators provide information about the buildings that can be used to evaluate their renovation needs:

\section{- Accessibility of the building}

The 'accessibility of the building' indicator refers to the percentage of buildings with no lifts within the census tract. The accessibility of a home refers to whether a person in a wheelchair can go from the street to the interior of their home without the help of another person. Having a lift in the building is one of the key aspects needed to guarantee the quality of life of residents and one of the main challenges that serves as motivation to carry out a comprehensive renovation. While the benefits of long-term energy savings do not usually represent a strong motivation for neighbours, the improvement of accessibility is a benefit that is perceived as necessary and immediate for residents.

- Conservation state of the building

Knowing the conservation state of a building is important to detecting the need for renovation. A building in a poor state of conservation implies a greater need for intervention to adapt it to the necessary quality and safety requirements.

In the criteria used, the number of defective and derelict buildings is evaluated through the data provided by EUSTAT at the census tract level. The indicator used to measure it is the percentage of buildings in very bad condition within the census section.

- Energy efficiency of the building envelope

Buildings constructed before the entry into force of the regulations that required homes to be provided with thermal insulation (Basic Building Standard NBE-CT-79 on Thermal Conditions in Buildings) have major deficiencies in energy efficiency and poor conditions of comfort due to the lack of thermal insulation in the envelope.

The buildings built between 1940 and 1970 that have not been renovated have high energy consumption due to the large amount of energy required to be able to maintain adequate comfort conditions. Therefore, improving the energy conditions, in addition to improving comfort, will have an impact on energy consumption savings. The indicator 
chosen to measure this factor is the percentage of buildings built between 1940 and 1969 within the census section.

- Energy efficiency of the facilities

Buildings without a natural gas connection and homes without heating are a clear sign of vulnerability since these homes will not be able to maintain adequate comfort conditions. The improvement of the quality of life of residents through the energetic renovation of the buildings could be the determining factor that improves the habitability of the homes. To measure this aspect, a combination of two indicators is used: the percentage of homes without gas provided by a pipeline and the percentage of homes with inefficient heating.

\subsubsection{Socio-Economic Indicators}

The following two indicators provide information for the characterization of the resident population:

- $\quad$ Aging

The elderly population is a particularly vulnerable group in terms of accessibility and health. The aging population rate is a factor to consider in the need to improve accessibility conditions in the renovations to be carried out. The indicator used to measure ageing is the percentage of the population over 64 years of age within the census section.

- Family income

Family income establishes the socioeconomic profile of the areas to be prioritized. The AGREE project aims at providing successful pilot cases that can inspire other areas to embark on renovations using existing governance and financial tools. Thus, it focuses on a segment of the population whose income is at a certain threshold in order to be able to mobilize existing funds related to energy and accessibility renovations.

According to the Basque Government's grants program for the improvement of the energy efficiency and accessibility of residential buildings to individuals and communities of owners, as well as economic benefits such as the Income Guarantee (RGI), four types of groups can be distinguished (see Figure 1):

- Group 1: People with incomes between 9000 EUR/year and 13,000 EUR/year. From the maximum monthly amounts of the RGI for 2018, an average annual income of 12,000 EUR was established in this concept. On the other hand, funds in the form of non-refundable grants in these sections for works to improve energy efficiency (Type 2) and works to improve accessibility (Type 3 ) vary between $35 \%$ and $25 \%$ of the protectable budget up to a maximum of 5000 EUR for Type 2 and 5500 EUR for Type 3 works.

- Group 2: People with incomes from 13,001 EUR/year to 25,000 EUR/year. People in this annual income threshold do not receive financial benefits due to a lack of sufficient income, but they are eligible to receive non-refundable grants for works to improve energy efficiency (Type 2) and works to improve accessibility (Type 3) between $30 \%$ and $25 \%$ of the protectable budget up to a maximum of 5000 EUR for Type 2 works and 5500 EUR for Type 3 works. On the other hand, it is considered that these people can access qualified financing, the amount of which may reach the protectable budget, deducting non-refundable subsidies, where appropriate, up to a maximum of 18,000 EUR per home.

- Group 3: People with incomes between 25,000 EUR/year and 39,000 EUR/year. People with incomes greater than 25,000 EUR/year cannot be beneficiaries of individual aid, but they can obtain qualified financing as long as their annual income does not exceed 39,000 EUR.

- Group 4: People with incomes greater than 39,000 EUR/year are not eligible to benefit from qualified financing and therefore will have to request financing in the free market if they need it. 


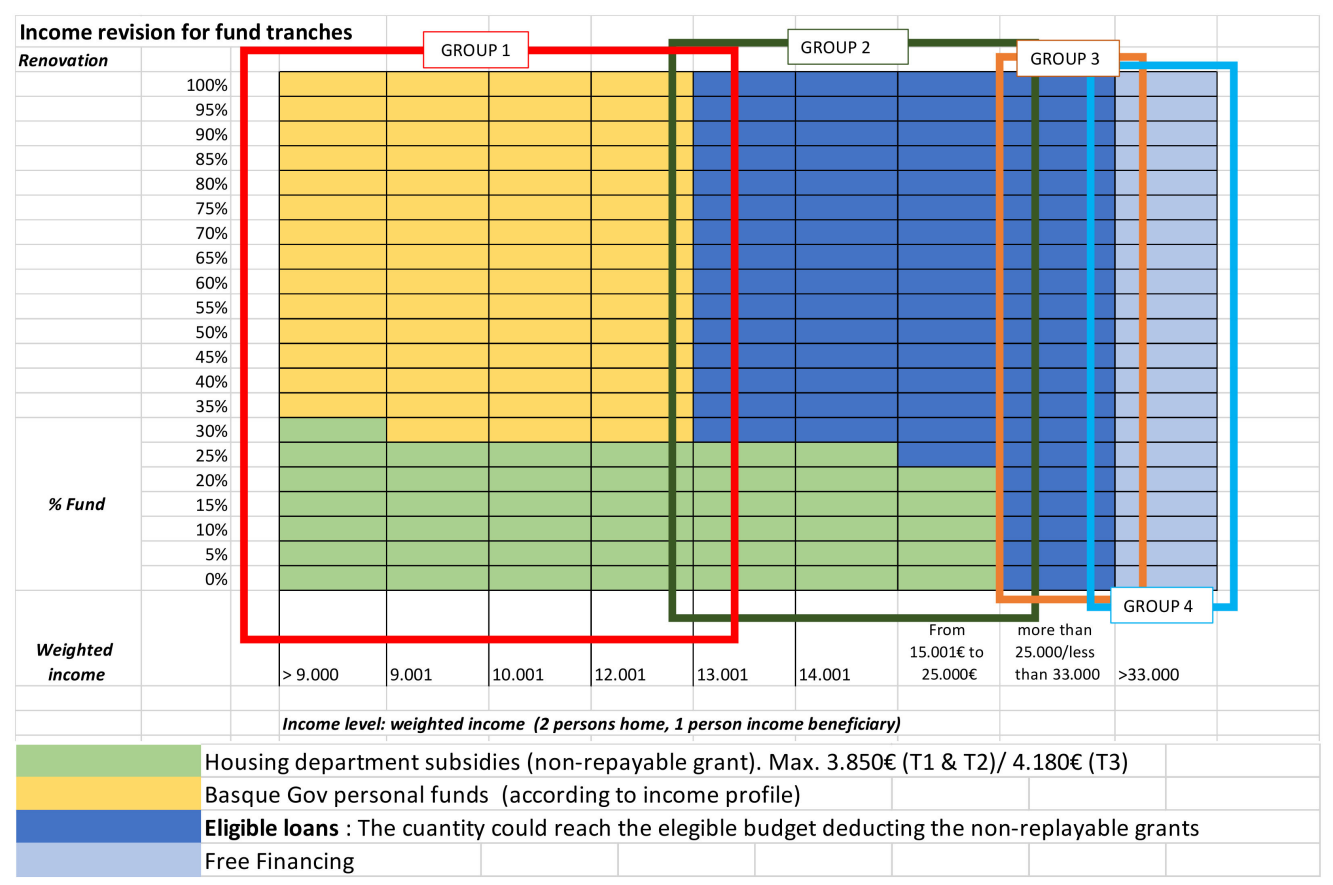

Figure 1. Income thresholds and funding types.

According to the goals established in the project, a lower income limit of 13,000 EUR/year and an upper income limit of 25,000 EUR/year were established as an income criterion to select the pilot areas, which corresponds to Group 2. People in this group can access personal funds to improve energy efficiency (Type 2) and accessibility (Type 3 ) and would be eligible for the granting of qualified financing (private loans) to be able to achieve $100 \%$ of the protectable budget of up to a maximum of 18,000 EUR per home. Therefore, the income indicator is defined as the average family income in the range of 13,000-25,000 EUR/year.

For each of the two identified fields, a "need or priority index" was calculated by weighting the associated indicators according to the identified policy priorities (see Table 1). The determination of the weight of each indicator was obtained based on technical experts proposals and validated by local authorities participating in the project. Moreover, a combined prioritisation index was calculated to define the census tracts on which the project should focus.

Table 1. Indicators and weights.

\begin{tabular}{|c|c|c|}
\hline Index & Indicator & Weight \\
\hline \multirow{5}{*}{$\begin{array}{l}\text { Need index according to the } \\
\text { state of the building }\end{array}$} & $\%$ of buildings without a lift & 2 \\
\hline & $\%$ of buildings in very poor condition & 1 \\
\hline & $\%$ of buildings built between 1940 and 1959 & 0.5 \\
\hline & $\%$ of homes without gas by pipeline & 0.25 \\
\hline & $\%$ of homes with inefficient heating & 0.25 \\
\hline \multirow{2}{*}{$\begin{array}{l}\text { Priority index according to the } \\
\text { socioeconomic profile }\end{array}$} & $\%$ of population older than 64 years & 2 \\
\hline & $\begin{array}{l}\text { Average family income in the range } \\
13,000-25,000 \text { EUR }\end{array}$ & 2 \\
\hline \multirow{2}{*}{ Combined prioritization index } & $\begin{array}{l}\text { Need index according to the state of } \\
\text { the building }\end{array}$ & 4 \\
\hline & $\begin{array}{l}\text { Priority index according to the } \\
\text { socioeconomic profile }\end{array}$ & 4 \\
\hline
\end{tabular}


The calculation of the indexes was carried out by adding the value of each indicator by its corresponding weight, and, finally, it was rescaled from 0 to 100 to offer a more intuitive result. The resulting map was classified into four intervals (Low, Low-Medium, Medium-High, and High) using the Natural Breaks Jenks Method.

\subsubsection{Opportunity Factor}

Decision-making using this methodology is also supported by an opportunity factor. As already mentioned in the definition of the universe of analysis, it consists of the analysis of existing plans and programs in the municipality through which certain areas have already been identified as relevant and, therefore, they represent an opportunity for renovation. Therefore, the methodology was applied in areas delimited according to municipal planning instruments of each of the three municipalities involved in the AGREE project. These plans are the Land Use Plan of Basauri (PGOU), in which three Areas of Integral Regeneration (ARIs) are declared; the Strategic Plan of Vitoria-Gasteiz 2015-2019, in which socio-urban studies were performed in nine areas; and the Municipal Housing Plan of Donostia, which identifies those areas in which accessibility needs to be improved.

\subsection{Stage 3: Detailed Diagnosis of Selected Areas}

In this step, a detailed diagnosis of the selected residential state is performed to determine the main needs and priorities of intervention. The detailed diagnosis aims to analyse the information gathered to design the Renovation Action Plans accordingly. The diagnosis is based on a detailed analysis on the building scale of the socio-economic situation, based on data gathered from public data sources, in a georeferenced way through the EUSTAT's NORA codes. A database structure is then defined, in which collected data for the area are placed and visualized through the GIS. This systematic data collection and processing allows for interoperability and replication as well as visualization.

\subsubsection{Indicators for the Selected Area}

The analysed data include demographic, accessibility, building, and dwelling indicators by postal address as shown in Table 2. Moreover, some indicators are related to obtaining diagnoses on specific issues, such as the elderly population living in buildings without a lift. The following table presents the data used and their sources. As can be seen, most of the data sources are generic, while for specific analyses, the sources used need to be provided by the City Council or the sectoral administration.

The indicators for the detailed analysis are built on these data and, as a result, population indicators, accessibility indicators, building indicators, and dwelling indicators are obtained and visualized in the GIS (see Figures 7-16 in Section 3.2).

\subsubsection{Renovation Interest}

Another opportunity factor included in the analysis is the willingness of and/or demand by residents to renovate their homes. A possible way to measure this factor is by carrying out personal interviews with key stakeholders, such as community leaders, property managers, and municipal technicians from the Housing, Urban Planning, and Social Affairs departments, and conducting surveys among residents.

The methodology envisages the holding of informative discussions, meetings, and workshops with different stakeholders divided by focus groups. The objective is to jointly identify and analyse the main barriers and opportunities from their own experiences as well as to develop the diagnosis to determine the main needs and the priorities of intervention.

These dynamics would enable us to know first-hand the initial situation of the neighbourhood through a diagnosis, and the data provided can be statistically analysed so that further communication activities directed to the residents by the municipalities could be designed accordingly. The location of those residents who have shown interest would be aggregated and visualized in the GIS, so it can be part of the detailed diagnosis. Based on this diagnosis, Action Plans to promote community organization and articulate the 
information, communication, and participation of different agents throughout the entire renovation process are designed.

Table 2. Name of the field and data sources.

\begin{tabular}{|c|c|c|c|c|}
\hline Name of Field_AGREE & Description & Source & Year & Frequency Update \\
\hline VIVTOT & $\begin{array}{l}\text { Total number of dwellings by } \\
\text { postal address }\end{array}$ & Real state Cadastre & 2019 & Annual \\
\hline POBTOT & Total population by postal address & Municipal Register of Inhabitants & 2019 & Annual \\
\hline N_HOMBR & Number of men by postal address & Municipal Register of Inhabitants & 2019 & Annual \\
\hline N_MUJER & Number of women by postal address & Municipal Register of Inhabitants & 2019 & Annual \\
\hline N_MA65 & $\begin{array}{l}\text { Population over } 65 \text { years of age by } \\
\text { postal address }\end{array}$ & Municipal Register of Inhabitants & 2019 & Annual \\
\hline N_MA79 & $\begin{array}{l}\text { Population older than } 79 \text { years by } \\
\text { postal address }\end{array}$ & Municipal Register of Inhabitants & 2019 & Annual \\
\hline N_ME15 & $\begin{array}{l}\text { Population under } 15 \text { years of age by } \\
\text { postal address }\end{array}$ & Municipal Register of Inhabitants & 2019 & Annual \\
\hline POBNAC & $\begin{array}{l}\text { Population of national origin by } \\
\text { postal address }\end{array}$ & Municipal Register of Inhabitants & 2019 & Annual \\
\hline POBEXTR & $\begin{array}{l}\text { Population of foreign origin by } \\
\text { postal address }\end{array}$ & Municipal Register of Inhabitants & 2019 & Annual \\
\hline pP_MA65 & $\begin{array}{c}\text { Percentage of portal population over } 65 \\
\text { years old, by postal address }\end{array}$ & Municipal Register of Inhabitants & 2019 & Annual \\
\hline pP_MA79 & $\begin{array}{l}\text { Percentage of portal population over } 79 \\
\text { years old, by postal address }\end{array}$ & Municipal Register of Inhabitants & 2019 & Annual \\
\hline ASCENSOR & The building has a lift, by postal address & $\begin{array}{c}\text { Department of Industry of the } \\
\text { Basque Government }\end{array}$ & 2019 & Annual \\
\hline ENV_ASC & $\begin{array}{l}\text { Buildings with an aging population and } \\
\text { no lift, by postal address }\end{array}$ & $\begin{array}{l}\text { Cross between the Municipal Register of } \\
\text { Inhabitants/cadastre }\end{array}$ & 2019 & Annual \\
\hline VIV_ALQ & $\begin{array}{l}\text { Number of homes for rent, by } \\
\text { postal address }\end{array}$ & $\begin{array}{c}\text { Basque Housing Observatory based on } \\
\text { the data from the Register of Bonds } \\
\text { and Contracts }\end{array}$ & 2019 & Annual \\
\hline pV_ALQ & $\begin{array}{l}\text { Percentage of portal housing for rent, by } \\
\text { postal address }\end{array}$ & $\begin{array}{l}\text { Basque Housing Observatory based on } \\
\text { the data from the Register of Bonds } \\
\text { and Contracts }\end{array}$ & 2019 & Annual \\
\hline VIV_VAC & $\begin{array}{l}\text { Number of empty houses, by } \\
\text { postal address }\end{array}$ & $\begin{array}{c}\text { Cross between the Municipal Register } \\
\text { of Inhabitants/cadastre }\end{array}$ & 2019 & Annual \\
\hline $\mathrm{pV}_{-} \mathrm{VAC}$ & $\begin{array}{l}\text { Percentage of empty portal houses, by } \\
\text { postal address }\end{array}$ & $\begin{array}{c}\text { Cross between the Municipal Register } \\
\text { of Inhabitants/cadastre }\end{array}$ & 2019 & Annual \\
\hline VIV_AYUD & $\begin{array}{l}\text { Number of homes that have received } \\
\text { social assistance, by postal address }\end{array}$ & $\begin{array}{l}\text { Cross between the Municipal Register of } \\
\text { Inhabitants/social services }\end{array}$ & 2019 & Annual \\
\hline p_V_AYUD & $\begin{array}{l}\text { Percentage of homes on the portal that } \\
\text { receive social assistance, by } \\
\text { postal address }\end{array}$ & $\begin{array}{l}\text { Cross between the Municipal Register of } \\
\text { Inhabitants/cadastre }\end{array}$ & 2019 & Annual \\
\hline ITE & $\begin{array}{l}\text { A Technical Building Inspection (ITE) has } \\
\text { been performed, by postal address }\end{array}$ & $\begin{array}{l}\text { Basque Housing Observatory based on } \\
\text { data from EuskoRegite (the Basque } \\
\text { Country Government's platform for the } \\
\text { registration of Buildings of the Basque } \\
\text { Country that have undergone a Technical } \\
\text { Inspection) except for Vitoria-Gasteiz * }\end{array}$ & 2019 & Annual \\
\hline ITE_EE & Global EE Indicator, by postal address & $\begin{array}{l}\text { Basque Housing Observatory based on } \\
\text { data from EuskoRegite }\end{array}$ & 2019 & Annual \\
\hline OBRAFACH & $\begin{array}{l}\text { Works on the facade have been carried } \\
\text { out in the last } 10 \text { years, by postal address }\end{array}$ & $\begin{array}{c}\text { Municipal urban planning department } \\
\text { based on building construction } \\
\text { works licenses }\end{array}$ & 2020 & Annual \\
\hline OBRACUB & $\begin{array}{l}\text { Roof works have been carried out in the } \\
\text { last } 10 \text { years, by postal address }\end{array}$ & $\begin{array}{c}\text { Municipal urban planning department } \\
\text { based on building construction } \\
\text { works licenses }\end{array}$ & 2020 & Annual \\
\hline
\end{tabular}

* In Vitoria-Gasteiz, the City Council has its own application that controls ITEs almost in real-time. 


\section{Results}

As part of the AGREE project, the proposed methodology was applied in Basauri, Donostia-San Sebastian, and Vitoria-Gasteiz. In the three municipalities, different municipal planning instruments pointed out some specific areas that allowed us to carry out the application of the methodology more specifically rather than analysing the whole municipal area. As an example, the results of the methodology's application in the case of Basauri are presented in this section.

\subsection{Prioritization of Renovation Areas (Stages 1 and 2)}

As a result of limiting the universe of analysis for the Basauri case study, the buildings shown in grey in Figure 3 are those that correspond to homogeneous sets of multifamily residential buildings with three or more floors built between 1940 and 1970. Then, the methodology on the census section scale was applied to three areas (Clemente Beltrán de Heredia, Federico Mayo, and Hernán Cortes) considered to be opportunity factors because they were selected for urban regeneration in the Land Use Plan of Basauri (PGOU) and identified as Areas of Integral Renovation (ARIs). These areas are marked by the blue dotted line in Figures 3-5. As shown in the following figures, the resulting indexes are represented in a scale of ranges using the Natural Breaks Jenks Method (Figure 2), which provides a benchmark between census tracts.

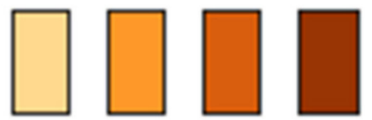

Figure 2. Ranges from "Low" to "Low-Medium", "Medium-High", and "High".

The application of the methodology on the census tract scale provided the following range, which shows the highest index for those census tracts located in the Federico Mayo and Hernán Cortés areas regarding the state of the building (Figure 3).

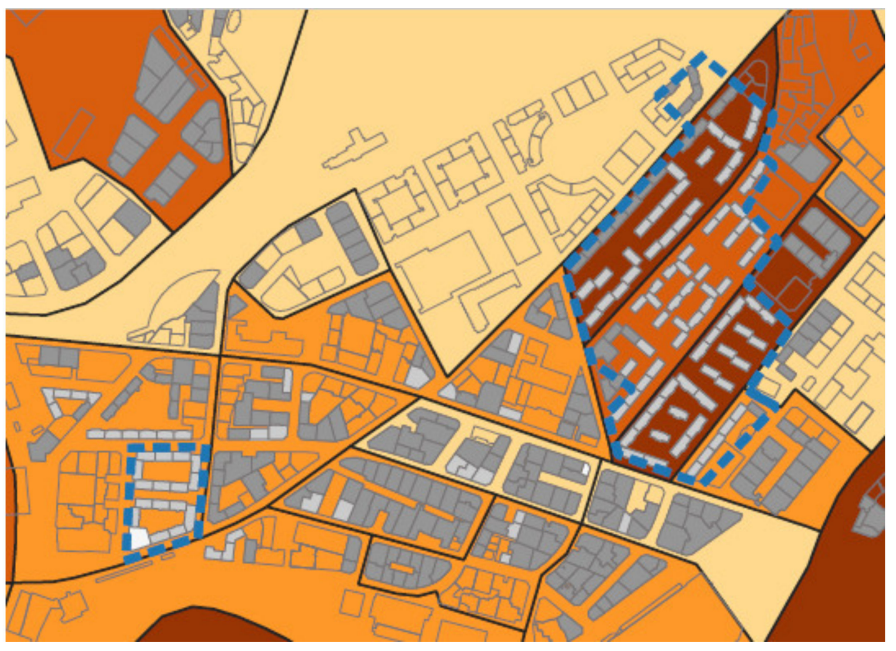

(a)

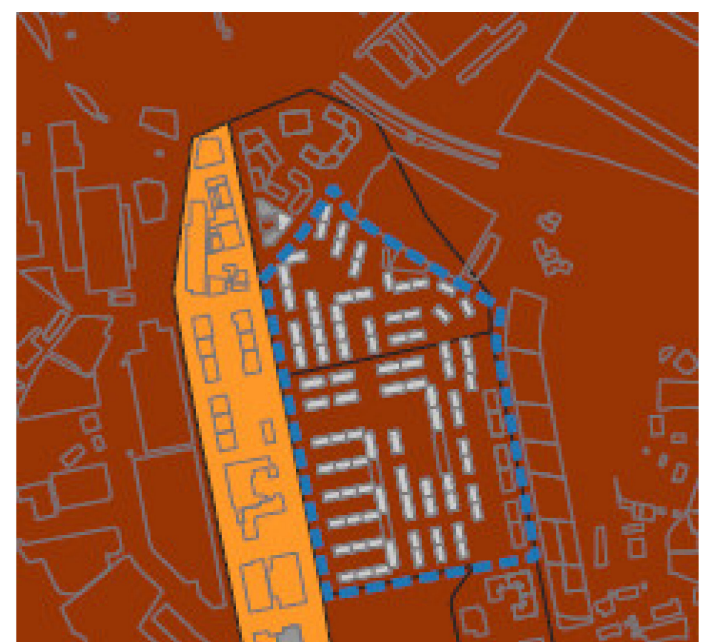

(b)

Figure 3. Need index according to the state of the building: (a) Clemente Beltrán de Heredia and Federico Mayo; (b) Hernán Cortes.

The Clemente Beltrán de Heredia and Federico Mayo areas' census tracts show a higher priority index than that of Hernan Cortes according to their socio-economic profile (Figure 4). 


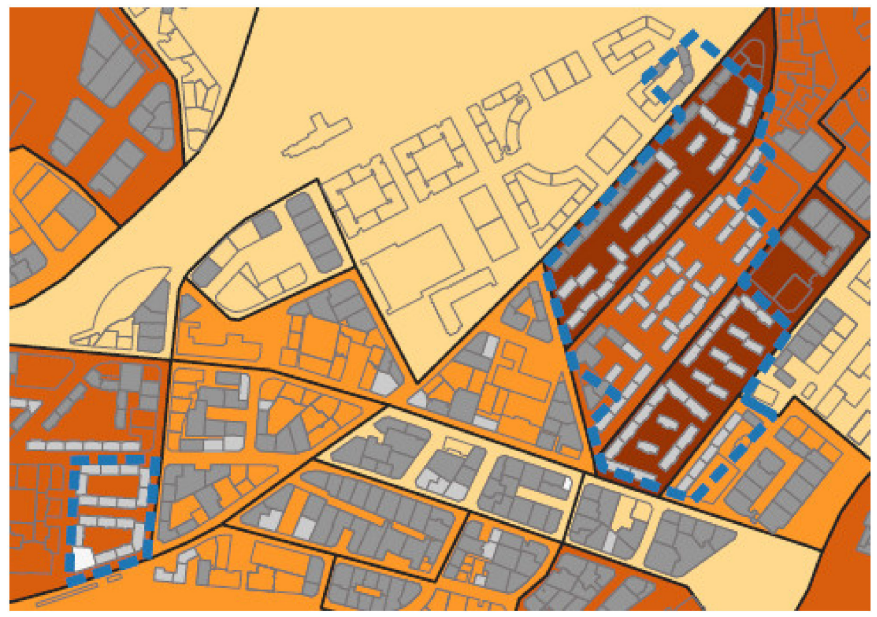

(a)

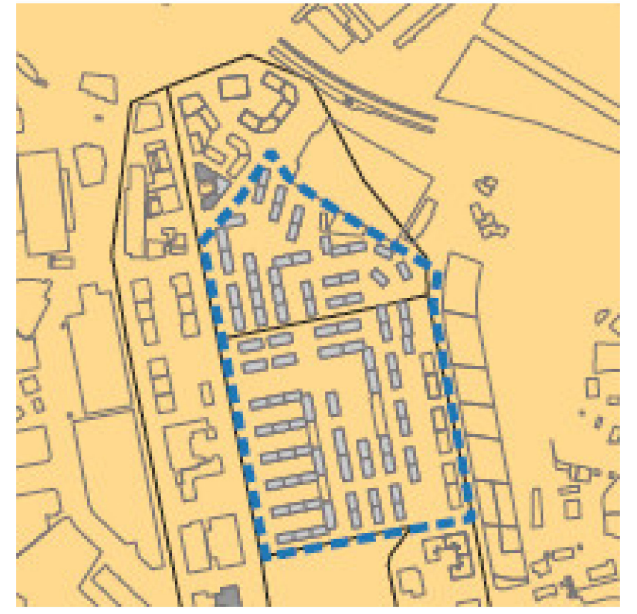

(b)

Figure 4. Priority index according to the socioeconomic profile: (a) Clemente Beltrán de Heredia and Federico Mayo; (b) Hernán Cortés.

The combined prioritization index for Basauri as shown in Figure 5 is higher for the areas of Federico Mayo and Hernán Cortes than for the area of Clemente Beltrán de Heredia.

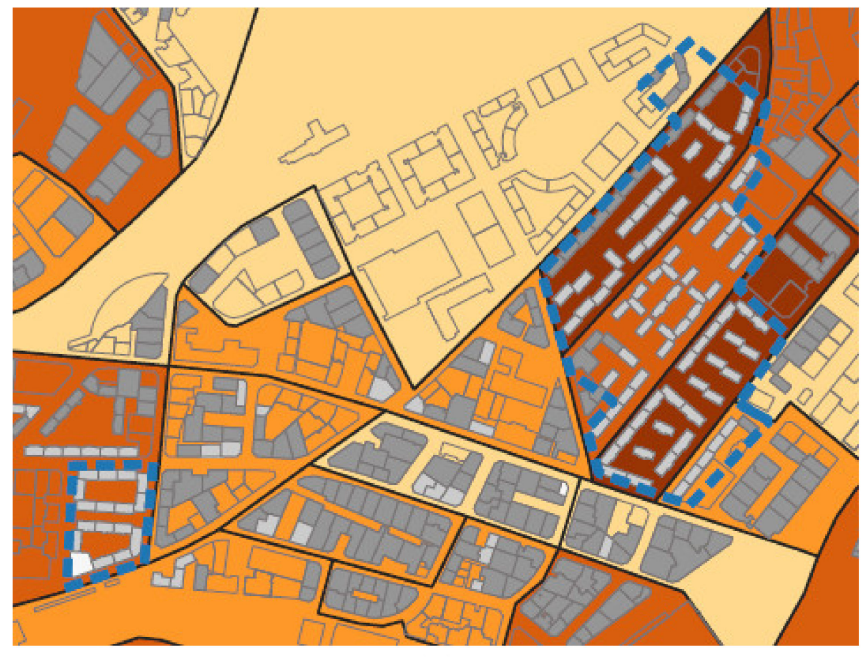

(a)

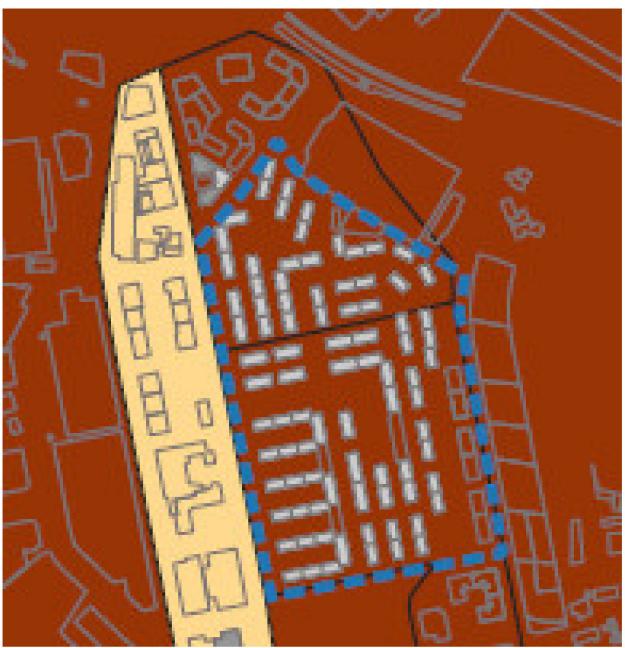

(b)

Figure 5. Combined prioritization index for Basauri: (a) Clemente Beltrán de Heredia and Federico Mayo; (b) Hernán Cortés.

Both prioritized areas of Federico Mayo and Hernán Cortés are very similar in terms of the number of dwellings and their characteristics, as well as from the population characteristics point of view. Finally, the Federico Mayo area was selected for the application of the detailed analysis.

The Federico Mayo area covers four different census sections. According to the range scale (see Figure 3a), the buildings have a high to medium-high need for renovation given their lack of accessibility, state of conservation, etc. Regarding the socio-economic profile (see Figure $4 \mathrm{a}$ ), the census sections show a range between low and medium. This indicates that the population has a high aging index and an income index in the range that enables them to afford the renovation of their buildings and provides access to both specific renovation aid and loans. 


\subsection{Detailed Analysis of the Selected Area (Stage 3)}

The Federico Mayo area, also known as Ariz, is located in the northern part of Basauri's municipality. The buildings in this area were built in the 1950s by the National Institute of Housing as social housing to meet the residential need of the massive population of workers who arrived to work in this industrial municipality.

The neighbourhood occupies an extension of $4.63 \mathrm{Ha}$ and has a density of $189 \mathrm{dwellings/Ha.}$ Most of the buildings have a northeast-southeast orientation around the longitudinal streets of Nagusia, León, Gaztela, and Cataluña and are limited by Bingen Anton Ferrero street, as shown in Figure 6.

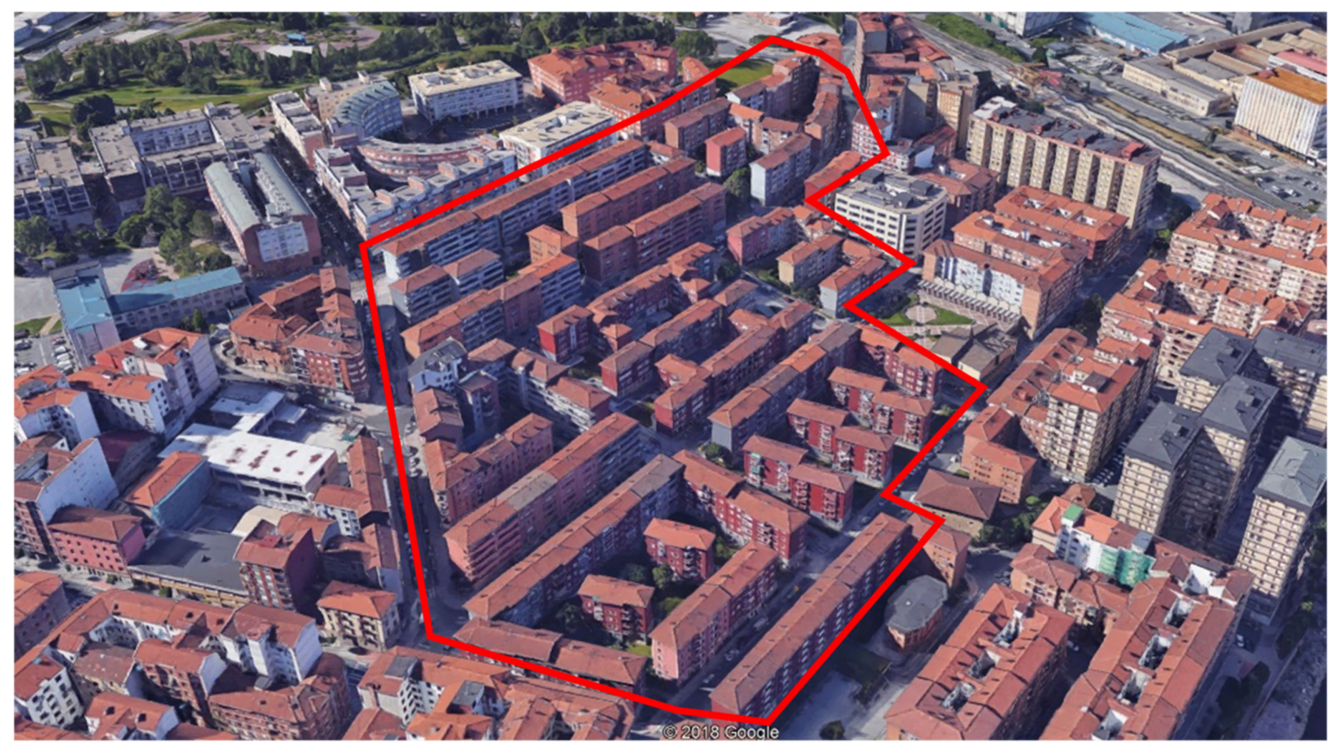

Figure 6. Aerial picture of Federico Mayo.

Other buildings adapt to the slope of the streets, creating internal areas between the buildings. Due to this orography, stairs that bridge the difference are needed in order to access buildings. Buildings have a ground floor and are three to four floors in height. Vehicles circulate on the main roads. As mentioned above, the area was declared an Area of Integral Renovation (ARI) in the initial approval of the Land Use Plan of Basauri (PGOU) in June 2018. Table 3 provides relevant information about Federico Mayo area.

Table 3. Data on Federico Mayo.

\begin{tabular}{lcc}
\hline \multicolumn{1}{c}{ Data } & Number & $\%$ \\
\hline Buildings (postal address) & 99 & \\
Number of Dwellings & 985 & \\
Total population & 2028 & \\
People $>65$ years & 408 & $20 \%$ of the total population \\
People $>79$ years & 231 & $57 \%$ of pop. $>65$ years \\
Dwellings with social welfare & 182 & $18 \%$ \\
\hline
\end{tabular}

To perform the detailed diagnosis, we gathered information on the postal address scale using the EUSTAT's NORA codes regarding the population's age, the accessibility of the buildings, and the energy ratings, as well as information regarding percentages of dwellings for rent and empty dwellings.

\subsubsection{Population Indicators}

There are 2028 residents in the Federico Mayo neighbourhood. A total of 20\% of these people are over the age of 65 and more than half of this aged population (57\%) are over the age of 79 . 
Figures 7 and 8 show where and how these elderly people are set, being homogeneously distributed over the neighbourhood. Two buildings stand out: the one located in Castilla street, in which more than $44 \%$ of the population is over 65 years old, of which $6 \%$ is also over the age of 79 ; and the one on Nagusia Avenue, where, despite the a low percentage of elderly residents $(37.5 \%)$, all of them are over 79 years old.

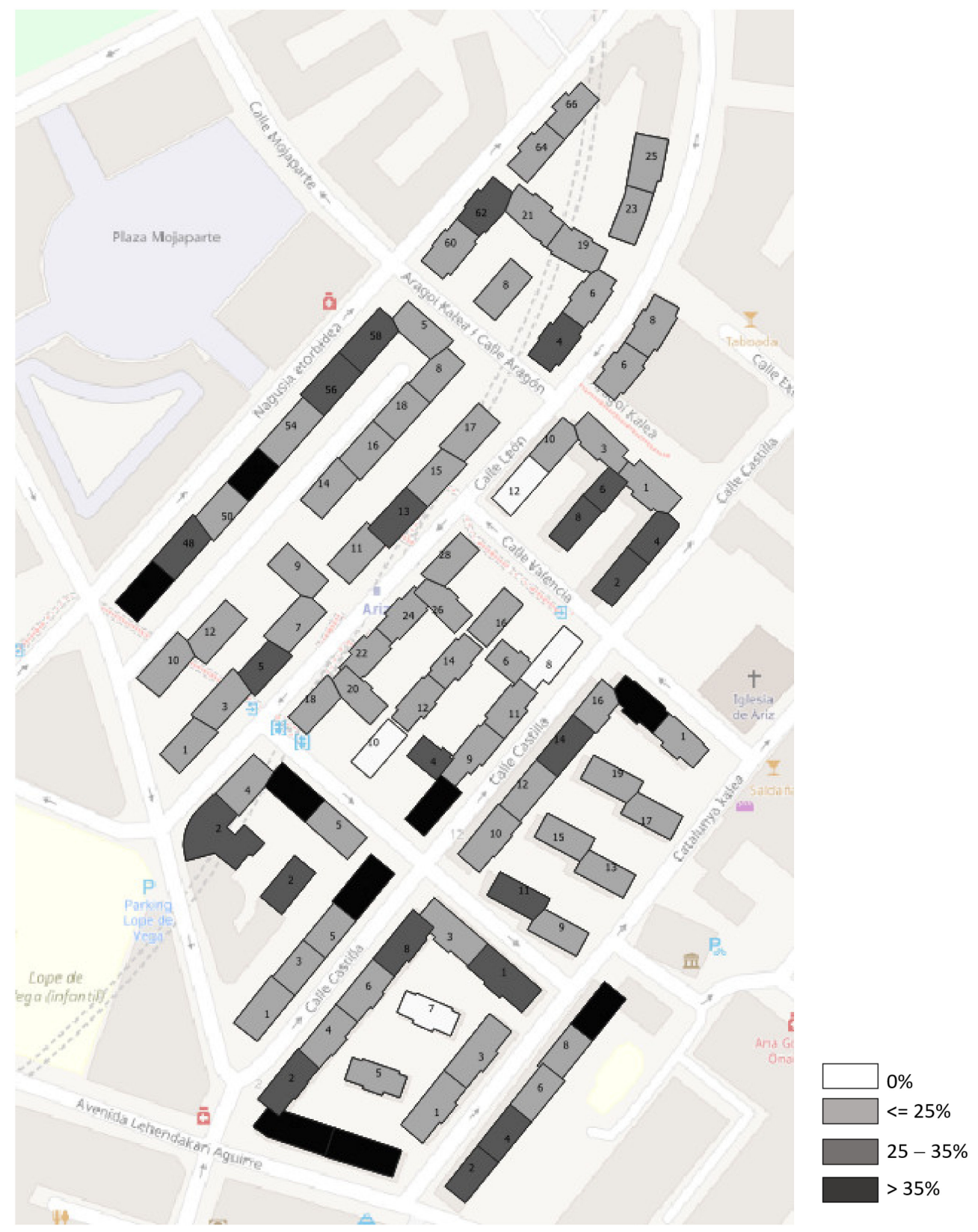

Figure 7. The location of residents over 65 years of age. 


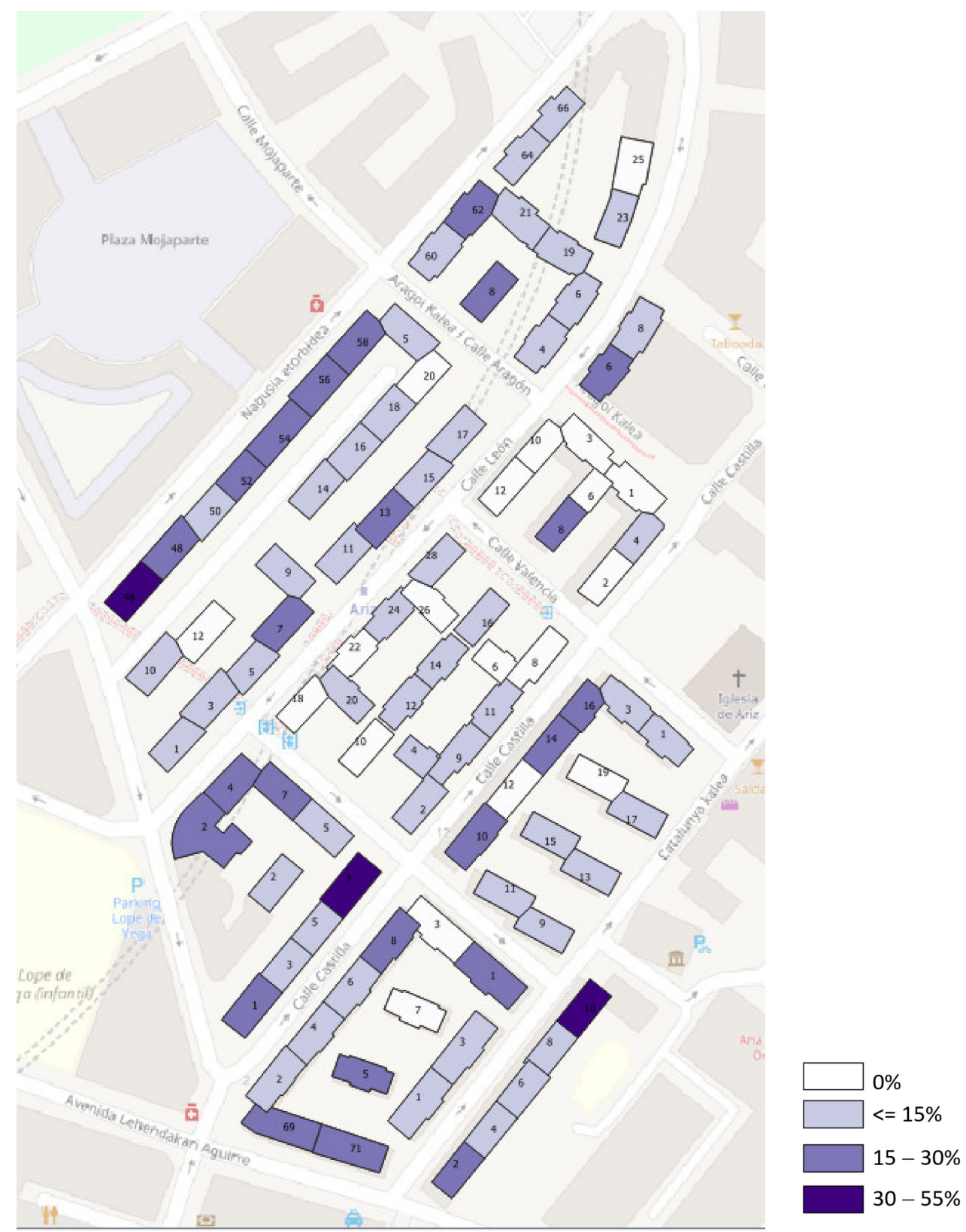

Figure 8. The location of residents over 79 years of age.

\subsubsection{Accessibility Indicators}

The orography of Federico Mayo is characterized by steep slopes that cause urban accessibility problems. In recent years, some lifts have been installed, but they have not completely solved the problem of accessibility in the neighbourhood.

Only $15 \%$ of the buildings have a lift, as shown in Figure 9 in green. The remaining buildings do not have a lift, or these data are not available. The owners of the five buildings in grey indicated that they carried out the installation of a lift, but data from the Department of Industry show that they do not have one yet.

To complement the accessibility indicator, Figure 10 shows those buildings without a lift and with a high proportion of elderly people. A total of $41 \%$ of the buildings do not have a lift and have residents older than 79 years, which reflects a real need to improve the accessibility of homes. 


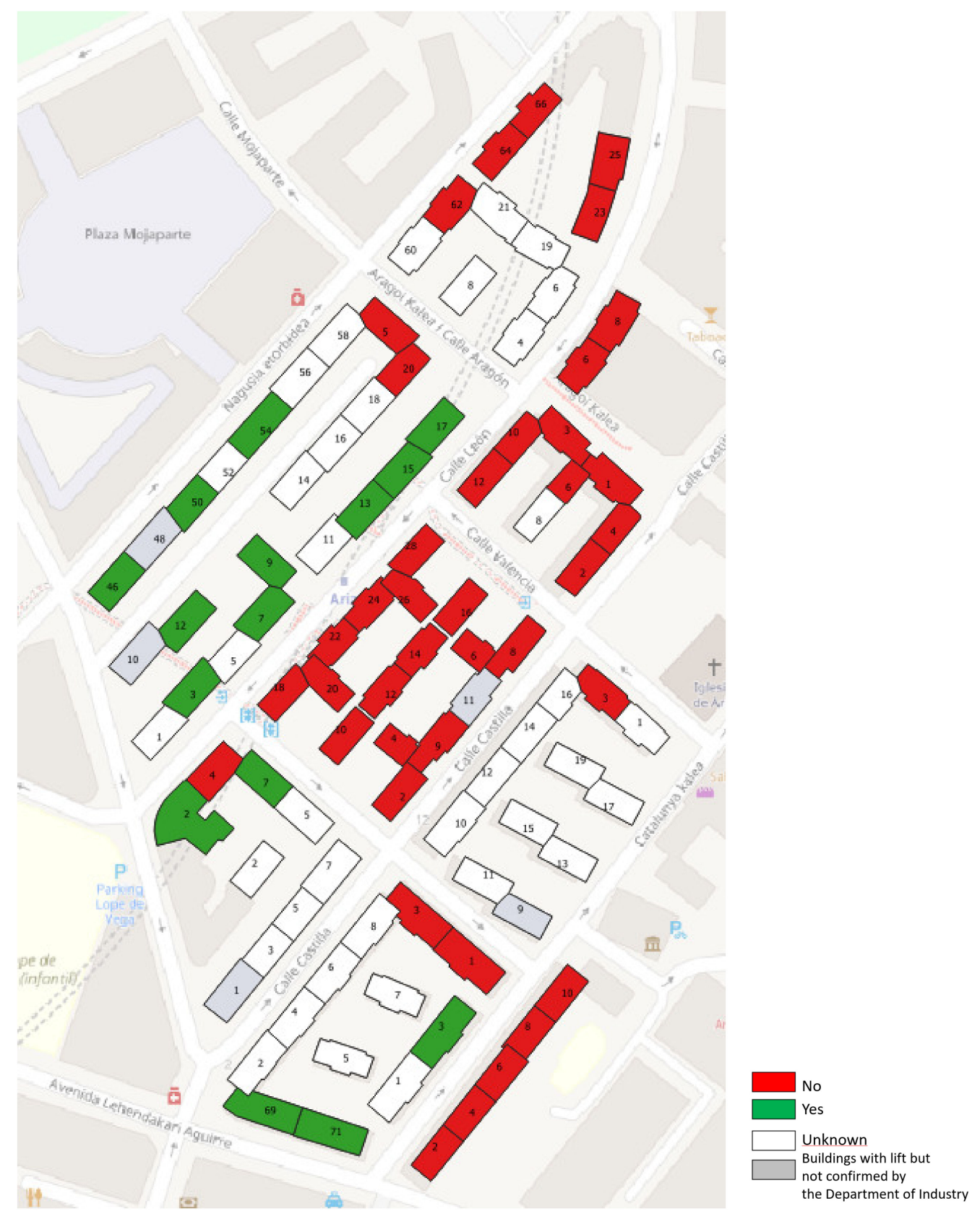

Figure 9. The location of buildings with or without a lift. 


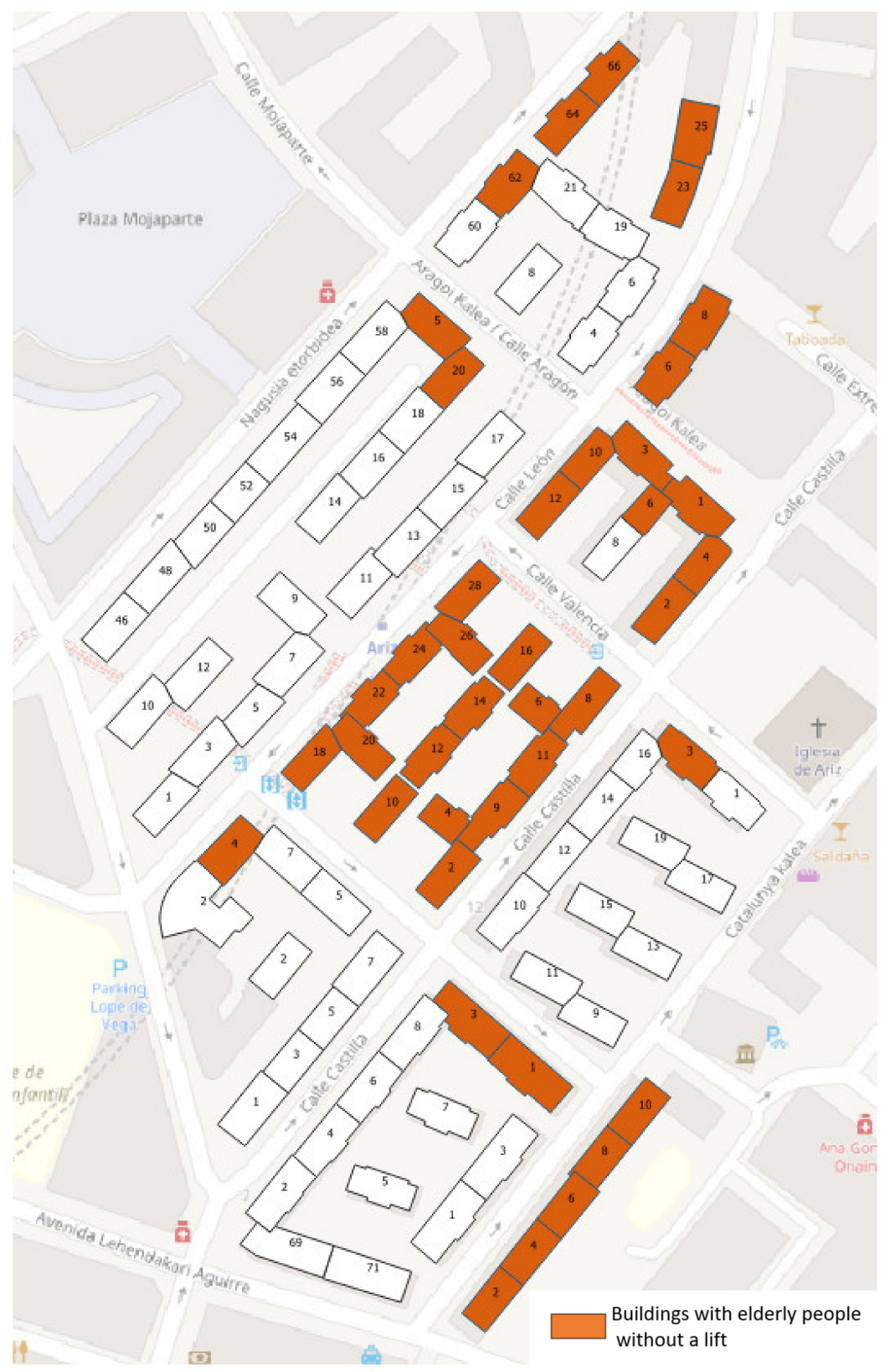

Figure 10. Buildings with elderly people without a lift.

It should be noted that the Special Fund for Accessibility approved by the Basque Government in December 2019 includes up to 100\% of the protected budget of non-refundable aid to improve the accessibility of homes for people over the age of 65 . For this reason, it is important to know how many people in the area could benefit from these special grants.

\subsubsection{Building Indicators}

Buildings over 50 years old (i.e., buildings built before 1970) must pass the Technical Inspection of Buildings (ITE), which is regulated by Decree 241/2012 of the Basque Government. Most of the buildings in Federico Mayo have a registered ITE, as shown in Figure 11. A total of $18 \%$ of the buildings do not have a registered ITE. 


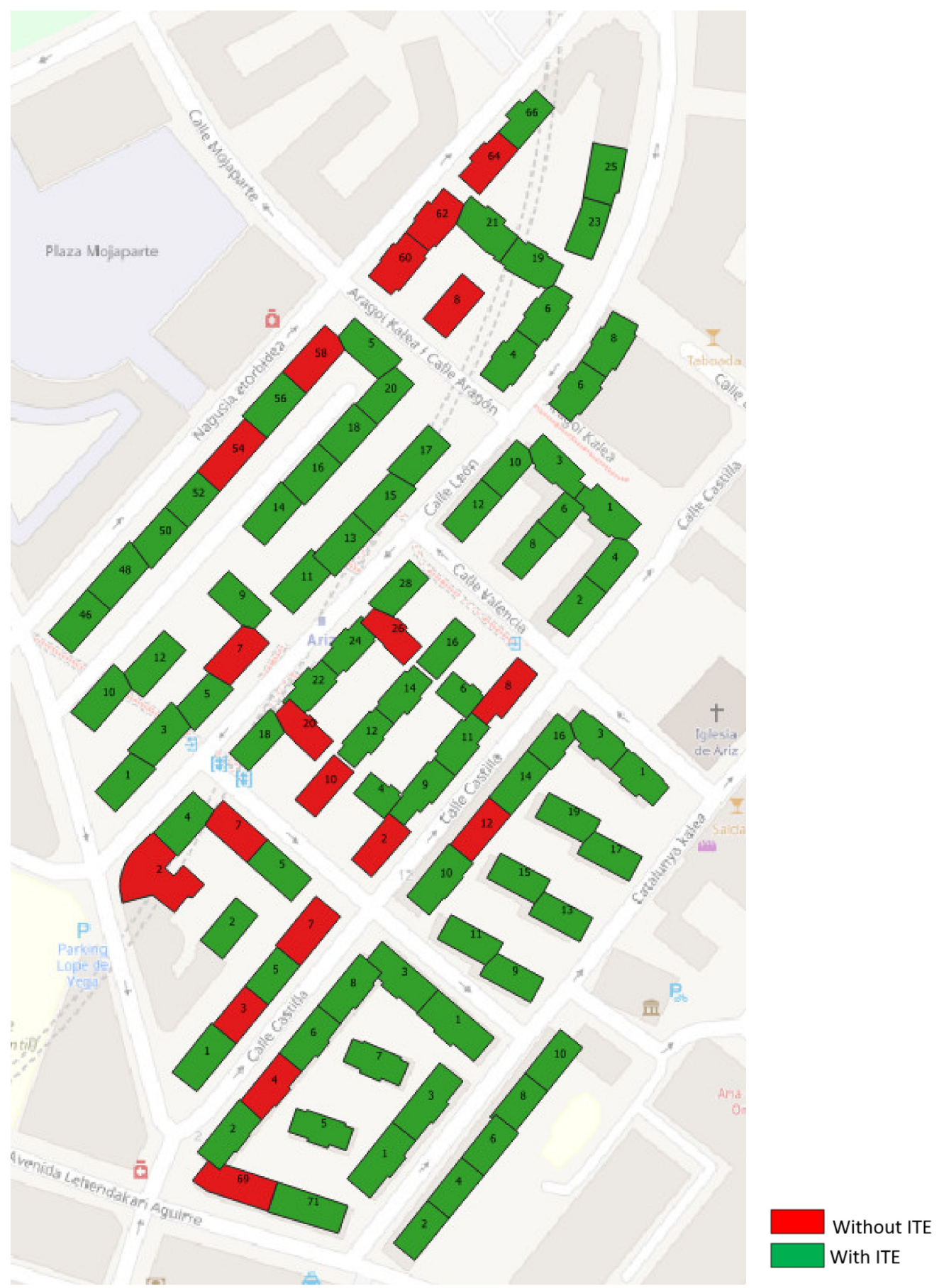

Figure 11. The location of buildings with an ITE and without an ITE.

Moreover, in 2013, an Energy Efficiency Certificate (CEE) was included in the ITE to evaluate the energy efficiency of a building by rating it from A, for the most efficient, to $G$, for the least efficient. Figure 12 shows that none of the buildings rate higher than an $\mathrm{E}$. The 12 buildings that have a registered ITE but for which no data are available on the global indicator of EE are shown in grey. 


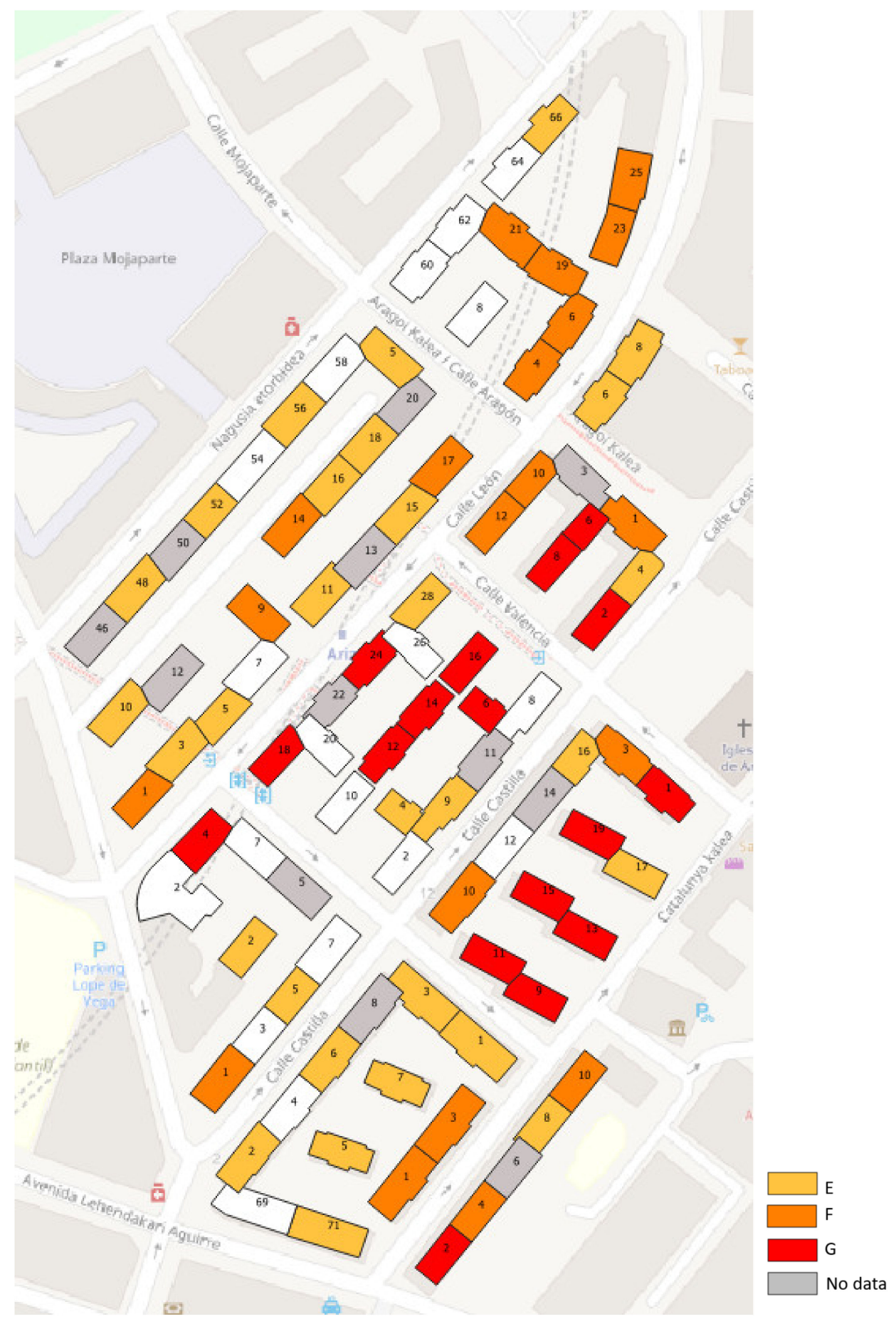

Figure 12. Global Indicator of EE.

\subsubsection{Dwelling Indicators}

Knowing the number of rented and empty dwellings per building is important to assess the available capacity for agreement or the willingness among the community to undertake the renovation of the building.

According to the data provided by the Housing Observatory based on the existing official rental contracts, in Federico Mayo, the total number of rented homes is 63, representing $7 \%$ of the total number of homes. As shown in Figure 13, $47 \%$ of the buildings contain rented dwellings. The highest percentages of rental housing are concentrated in two buildings, while the rest do not exceed $25 \%$. 


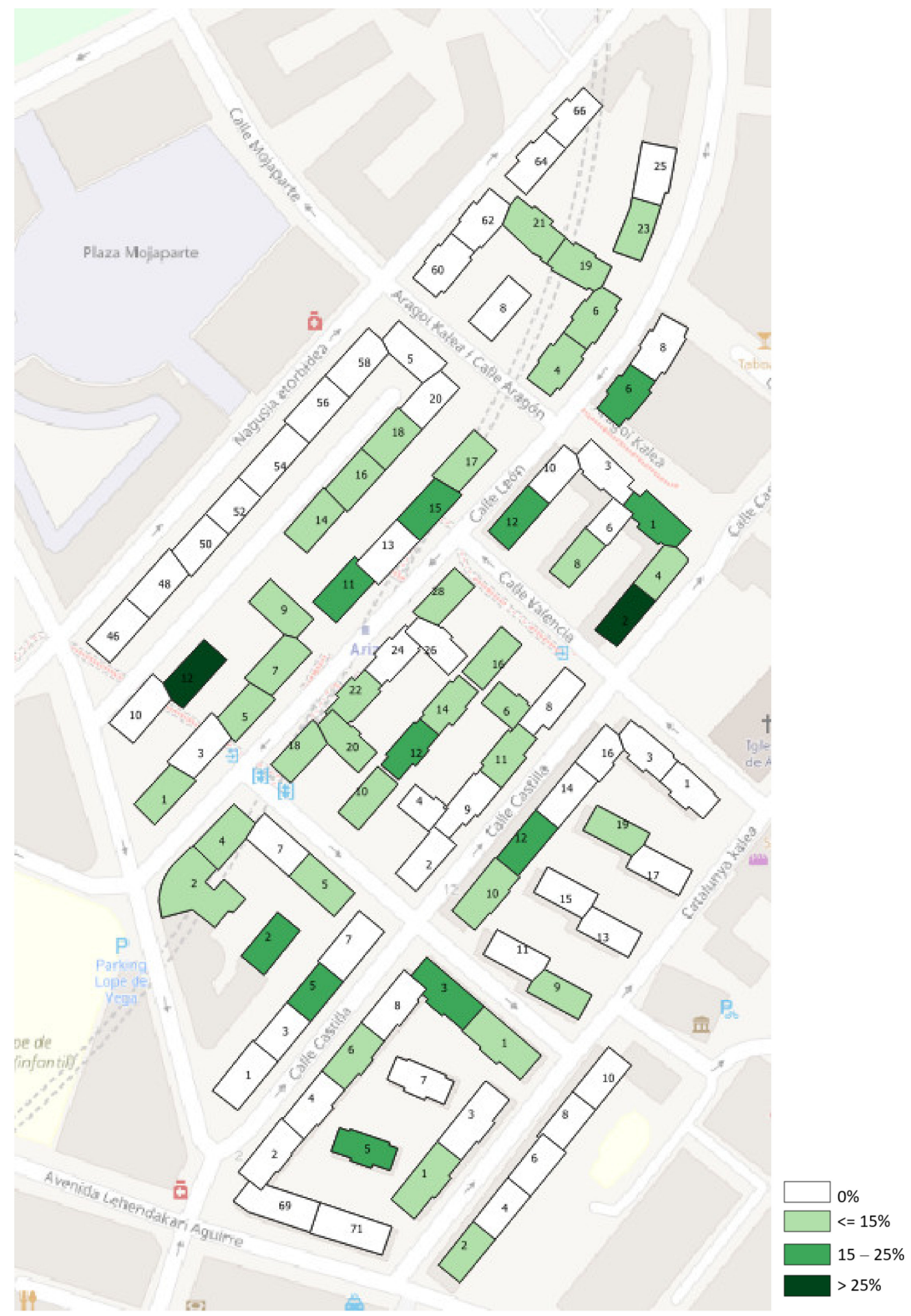

Figure 13. Percentage of rented dwellings.

Regarding the data on empty dwellings, a total of 94 empty apartments were counted, located in 57 buildings, as shown in Figure 14. Seven of these buildings have a high index of empty housing (more than one third), which may represent a barrier to agreement among the residents to undertake renovation works in the building. 


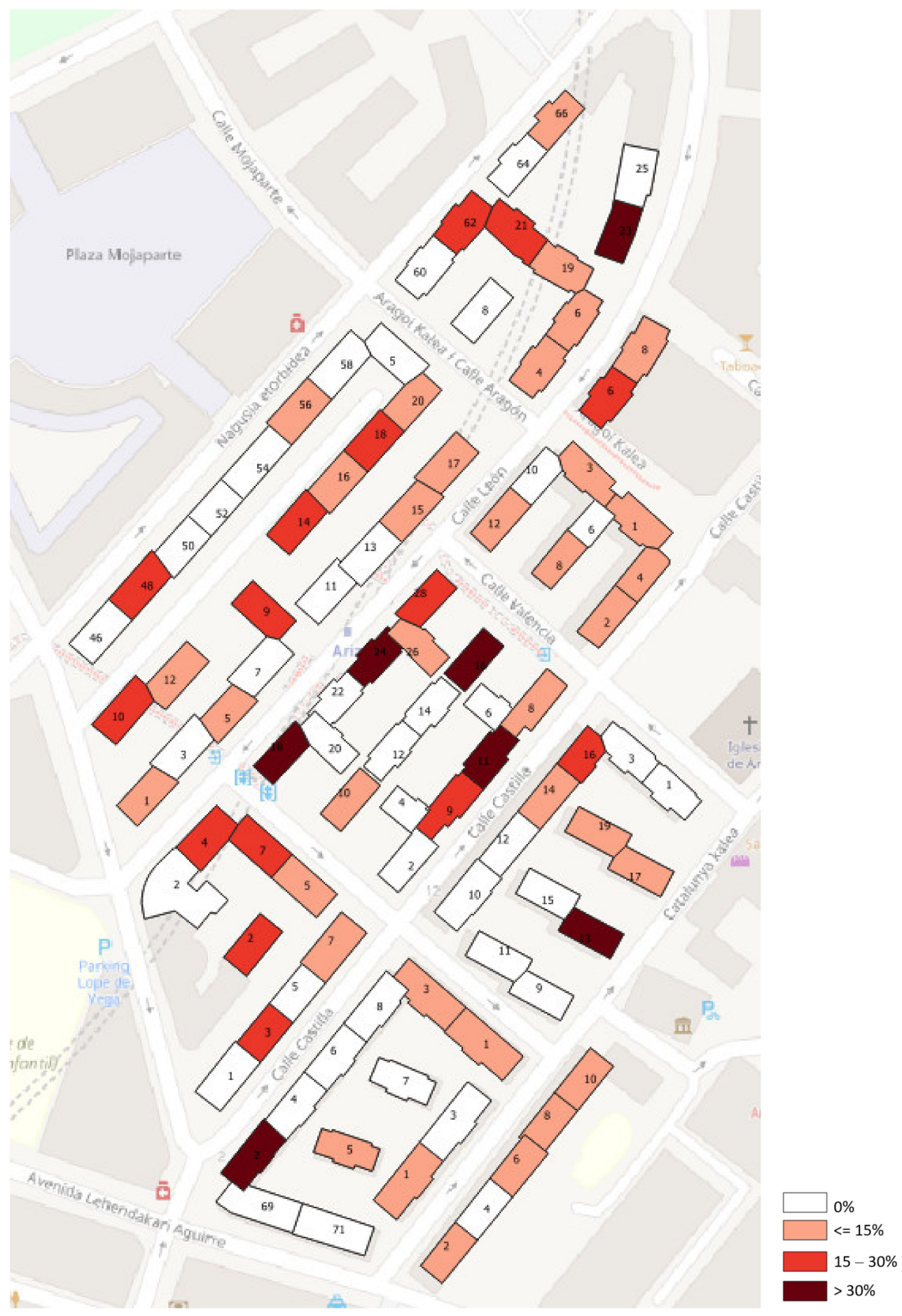

Figure 14. Percentage of empty dwellings.

Basauri's Municipal Social Services department indicated that 182 dwellings in the Federico Mayo area receive some kind of social welfare subsidy; this is $21 \%$ of the dwellings. As shown in Figure 15, these homes are distributed among the buildings (in $68 \%$ of the buildings). It must be considered that nine of these buildings show a very high percentage. 


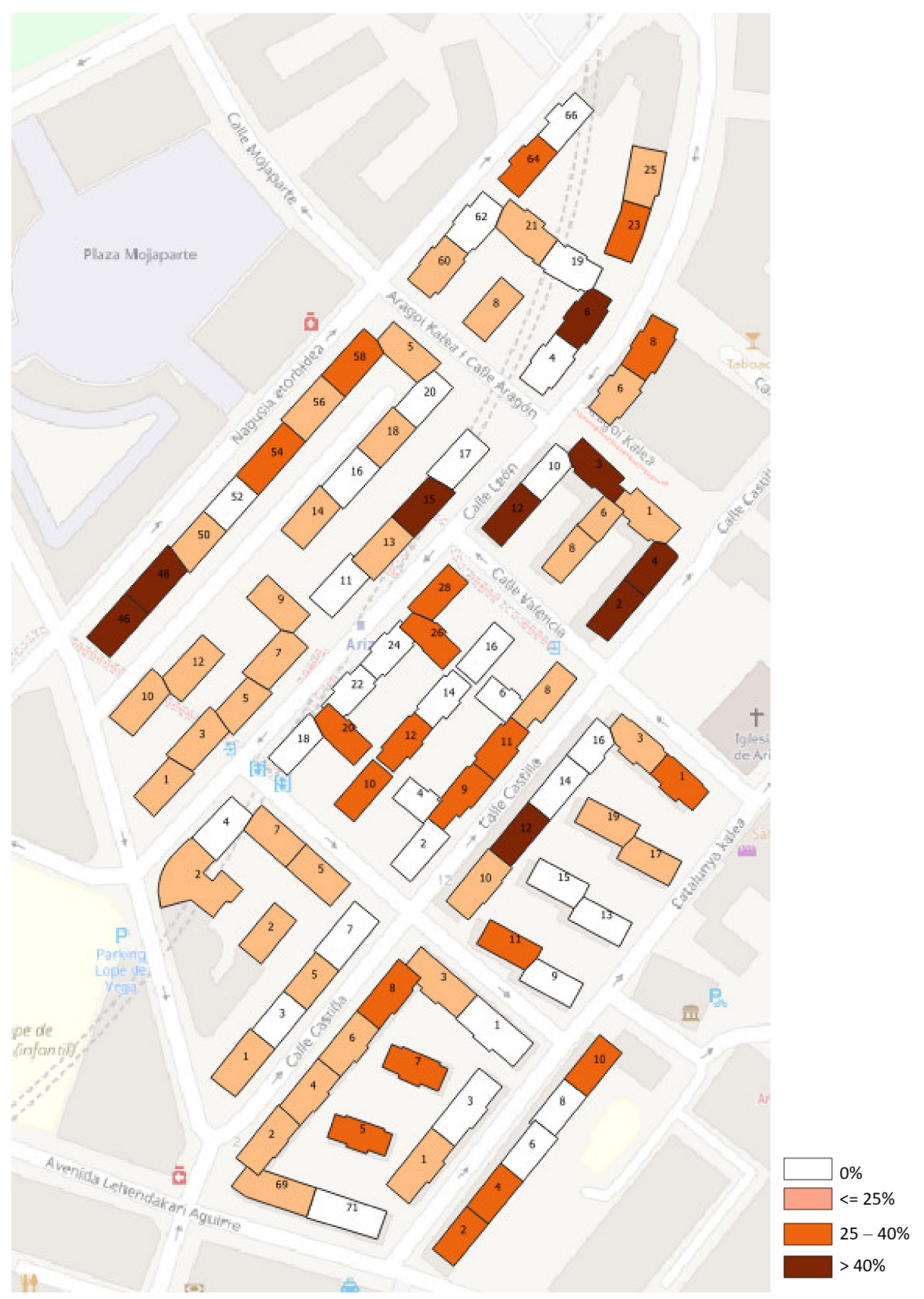

Figure 15. Percentage of dwellings that receive some kind of social welfare subsidy.

\subsubsection{Renovation Interest}

Due to the state of emergency declared in Spain in March 2020 because of COVID-19, the proposed methodology regarding the interest factor was adapted to the restricted circumstances. Face-to-face meetings and other activities with the residents of the selected areas could not be performed. Instead, a telephone service was set up by Basauri to provide information to residents that also allowed us to collect relevant information through a survey (whose data was used for statistical sampling of the area) about the following issues:

- interest in carrying out a home renovation;

- information about previous renovation works in the building;

- the priority of renovation actions: accessibility (lift installation), energy improvement (envelope renovation), aesthetic improvement (facade arrangement), or any kind of intervention derived from the compulsory Technical Building Inspection (ITE); and 
- the main difficulty encountered in renovating their home (building): the economic aspect (a lack of financial resources), the difficulty of the process (too complicated), a lack of agreement among neighbours, etc.

The location of those residents who showed interest was aggregated and visualized in the GIS and the data provided about their needs, priorities, and barriers to the renovation of their home were statistically analysed so that further communication activities directed to the residents by the municipalities could be designed accordingly.

A total of 10 people contacted the external telephone service set up by Basauri, thus showing their interest in the project and in renovating their home. Figure 16 shows the number of residents in the same building who showed interest, which is dispersed across the area.

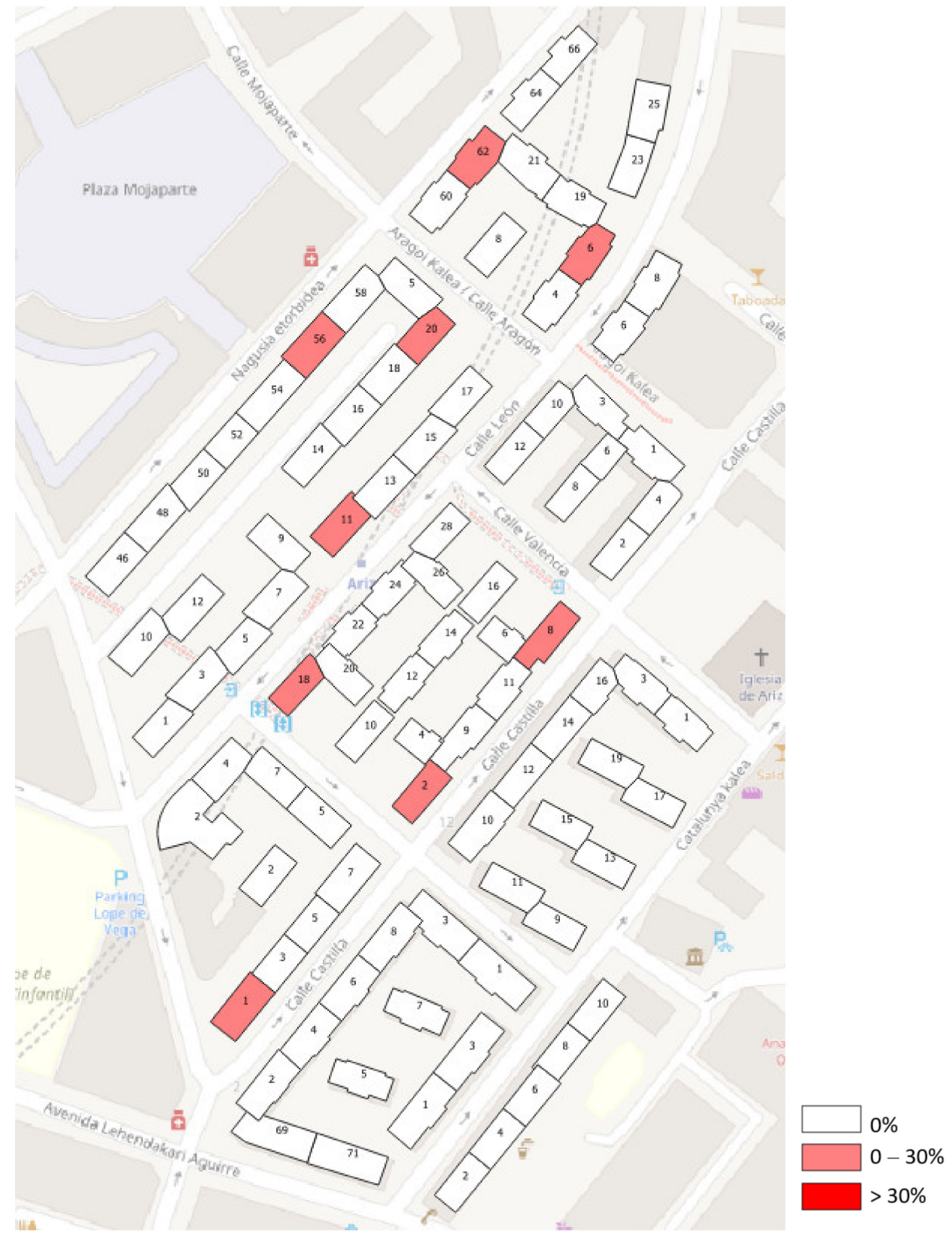

Figure 16. Percentage of residents who showed interest in renovating their home.

In addition to the location of interested residents shown in the figures above, the responses received were assessed in order to design future communication actions for residents and to adapt the participation strategy. A summary of the responses is given below: 
- $56 \%$ of the residents stated that they had not carried out any type of construction work (Figure 17);

- $67 \%$ of the residents stated that their priority for renovation works is focused on accessibility (Figure 18); and

- the economic aspect $(67 \%)$ and the difficulty of the renovation process itself $(22 \%)$ were identified as the main barriers to home renovation (Figure 19).

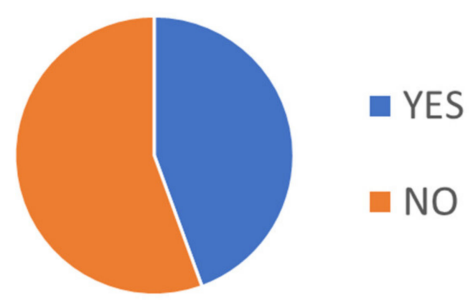

Figure 17. Construction works.

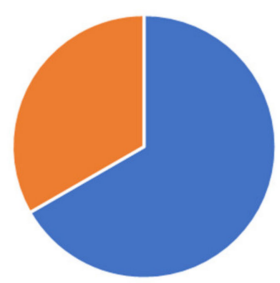

\section{- ACCESIBILITY - ENERGY IMPROVEMENT}

Figure 18. Priority of renovation works by type.
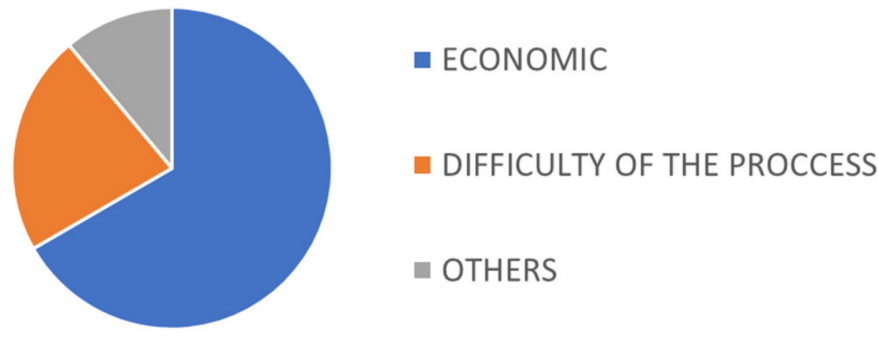

Figure 19. Barriers to renovation.

\section{Discussion and Conclusions}

4.1. Barriers and Opportunities Found in the Application of the Methodology

Several conclusions can be derived from the application of the proposed methodology in the case of Basauri. First, regarding the selection of the priority area for the AGREE case study, the assumption of the pre-selected areas for urban regeneration identified in the Land Use Plan of Basauri (PGOU) may have hindered the study from finding other areas with renovation needs. In this case, the pre-identified areas matched the universe of analysis established to fulfil the project's objective. However, even though the prioritized area for the pilot renovation case in Basauri seems to be a good fit for the objectives of the project, to develop a comprehensive renovation plan, the municipality of Basauri will probably need to conduct further analysis. These kinds of practical constraints, e.g., the existence of previous plans that need to be assumed, abound in practice; however, it is necessary to identify the potential skews they introduce into the conducted research. Moreover, these kinds of contextual factors are case-specific and entail a careful application of general methodologies in order to account for each municipality's policy context.

Secondly, regarding the identification of data sources and data collection, this methodology considers the importance of the interoperability and accessibility of the data, the scale of the data, the currency of the data, etc. Data formats from different public sources 
were not homogeneous, and therefore extra work was required to make them compatible; in particular, the reference to the NORA code was useful for building the database, but several data sources had to be adapted to this coding system. This is one of the main barriers regarding the systematization of this kind of methodology, and it underlines the need for clear and shared data protocols within public administrations.

Moreover, regarding the selection of indicators, the application of this methodology demonstrated the importance of sharing knowledge and practices among public authorities of different levels, in particular regarding data sources. As an example, data regarding accessibility (the existence of a lift in a building) had to be requested from the Department of Industry of the Basque Government, which manages the permits after the installation. One of the participating municipalities had these data and periodically asked for them, while the two others did not previously have this information and did not know where to find it.

Another important aspect is the scale of data collection and its influence on the analysis. Though the methodology considers socio-economic indicators on family income for the selection of the area (Stage 2), this information is provided at the census tract. The detailed diagnosis of the area (Stage 3) would be improved if the methodology included economic indicators as well, such as the economic capacity of residents to carry out a renovation. However, one of the main difficulties faced by the methodology in the detailed diagnosis phase is extracting data about the residents anonymously.

The involvement of municipal departments, such as the Social Action Department and the Citizen Participation Department, in the detailed analysis is also key to performing a good diagnosis. First, it enables us to contrast the information obtained in the indicators with the actual situation in an anonymous way; second, it enables us to detect other needs of the residents that may be complementary to the renovation of their buildings. These identified needs, on the other hand, can be key to motivate residents to change the scope of the construction works they had planned towards a more comprehensive intervention.

Finally, when applying the methodology, it is important to be able to adapt to unforeseen circumstances, such as the COVID-19 pandemic in this case, which impeded the collection of information on residents' needs and priorities as originally planned. The information was gathered through a different mechanism (a telephone service in this case), which yielded good results.

\subsection{Conclusions}

The proposed methodology could be a useful tool for planning municipal building renovation strategies and should help to tailor interventions to decarbonize the residential building stock. It analyses the municipality through an objective quantification based on socioeconomic and physical building criteria, providing a prioritization of areas that should first be intervened into as pilot cases.

In any case, this prioritization must be aligned with previous municipal policies, which are included as an opportunity factor in the selection of the area and contribute to accounting for the local path dependency of renovation policies. Political support from the municipality is also crucial for the prioritization of the selected areas, in order to ensure future implementation, and therefore it is important to engage both technical and political levels in the process and to contrast the results of the analysis.

The detailed analysis phase is critical for the planning stage. The more detailed the analysis of the situation of each building, the more tailored the Action Plan will be to the needs of the residents and the buildings. In this sense, communication with residents and property owners is key. At the beginning of the process, it would be convenient to identify a reference person with authority who can generate confidence among the residents and with whom they feel comfortable expressing themselves. Defining a good communication strategy (if possible, with help from the reference person or expert) is key to gathering information about the neighbourhood and its residents, which will help when performing the diagnosis and developing an appropriate action plan. 
The proposed methodology may benefit from further research on how to structure subjective experiences on the objectively descriptive data to be included in the detailed diagnosis, such as the residents' perceptions of the renovation processes. Surveys involving key stakeholders should be designed and structured in a way that allows for the inclusion of relevant information in the diagnosis phase.

The cost of renovation works is key to motivating residents to become involved in renovation processes. In addition to cost, the availability of public subsidies and loans to cover the cost is critical to the success of the process. The eligibility and the amount usually depend on the annual family income and the number of family members. For this reason, it is important to adjust the income ranges of the analysis to the existing grant and loan conditions and to plan viable actions, since different socio-economic and socio-demographic profiles require different approaches to renovation; in other words, a segmentation of renovation demand is needed in order to design appropriate strategies for each kind of renovation process.

To sum up, the proposed methodology provides a straightforward, realistic approach to the prioritization of areas for building renovation based on comparative analysis within the municipality. As such, it can be adapted beyond the Basque Country's context and, therefore, could be replicated at the national level, although some sources would need to be adapted to other regions' contexts. However, renovation actions are very complex processes involving different stakeholders, so governance and policy contexts matter; therefore, the support offered by municipal agencies, complemented with other resources such as offices located in the neighbourhood, close to residents, could overcome many of the difficulties by allowing constant and fluid communication, which will support the analysis of the selected areas, the design of policies, and successful deployment of proposed actions.

Author Contributions: Conceptualisation, P.M.-C. and O.N.; methodology, P.M.-C. and O.N.; validation, O.N. and P.M.-C.; formal analysis, O.N. and P.M.-C.; investigation, O.N. and P.M.-C.; writingoriginal draft preparation, O.N. and P.M.-C.; writing-review and editing, O.N. and P.M.-C.; visualisation, O.N.; supervision, P.M.-C.; project administration, P.M.-C. All authors have read and agreed to the published version of the manuscript.

Funding: This research was funded by the European Commission, grant number 847068 .

Institutional Review Board Statement: Not applicable.

Informed Consent Statement: Not applicable.

Data Availability Statement: eustat.com; Real state Cadastre; Municipal Register of Inhabitants; euskoregite.com.

Acknowledgments: Deep thanks to AGREE project's partners: the Basque Government's Departamento de Planificación Territorial, Vivienda y Transportes, Ensanche 21, Bidebi-Basauri, Donostiako Etxegintza and IHOBE.

Conflicts of Interest: The authors declare no conflict of interest. The funders had no role in the design of the study; in the collection, analyses, or interpretation of data; in the writing of the manuscript, or in the decision to publish the results.

\section{References}

1. European Commission. Energy Efficient Buildings. Available online: https://ec.europa.eu/energy/en/topics/energy-efficiency/ buildings (accessed on 13 December 2021).

2. BPIE. Future-Proof Buildings for all Europeans-A Guide to Implement the Energy Performance of Buildings Directive. 2019. Available online: http:/ / bpie.eu/publication/a-guide-to-implementing-the-energy-performance-of-buildings-directive/ (accessed on 13 December 2021).

3. Ulterino, M.; Bloom, E. Energy Efficient Buildings: Europe. Energy Efficient HVAC, Lighting, Insulation and Glazing, Building Controls, and Energy Service Companies: Market Analysis and Forecasts; Navigant Research: Chicago, IL, USA, 2014.

4. European Commission. Fostering Public Capacity to Plan, Finance and Manage Integrated Urban REGeneration for Sustainable Energy Uptake. FosterREG Project. Available online: https://cordis.europa.eu/project/id/649846 (accessed on 13 December 2021). 
5. European Commission. A Renovation Wave for Europe-Greening Our Buildings, Creating Jobs, Improving Lives; COM(2020) 662; European Commission: Brussels, Belgium, 2020.

6. BPIE. Long-Term Renovation Strategies and Local Building Renovation Initiatives: Case Studies from 8 Countries. 2020. Available online: http:/ / bpie.eu/publication/long-term-renovation-strategies-and-local-building-renovation-initiatives-case-studiesfrom-8-countries/ (accessed on 13 December 2021).

7. Energy Efficiency Financial Institutions Group (2015): Energy Efficiency-The First Fuel for the EU Economy. How to Drive New Finance for Energy Efficiency Investments. Available online: http:/ / www.eefig.com/index.php/the-eefig-report (accessed on 13 December 2021).

8. $\quad$ van Kempen, R.; Dekker, K.; Hall, S.; Tosics, I. (Eds.) Restructing Large Housing Estates in Europe; The Policy Press, University of Bristol: Bristol, UK, 2005; Chapter 1, pp. 1-17.

9. Conci, M.; Schneider, J. A district approach to building renovation for the integral energy redevelopment of existing residential areas. Sustainability 2017, 9, 747. [CrossRef]

10. Terés-Zubiaga, J.; Bolliger, R.; Almeida, M.G.; Barbosa, R.; Rose, J.; Thomsen, K.E.; Montero, E.; Briones-Llorente, R. Cost-effective building renovation at district level combining energy efficiency \& renewables-Methodology assessment proposed in IEA-Annex 75 and a demonstration case study. Energy Build. 2020, 224, 110280. [CrossRef]

11. Häkkinen, T.; Ala-Juusela, M.; Mäkeläinen, T.; Jung, N. Drivers and benefits for district-scale energy refurbishment. Cities 2019, 94, 80-95. [CrossRef]

12. Rose, J.; Thomsen, K.E.; Domingo-Irigoyen, S.; Bolliger, R.; Venus, D.; Konstantinou, T.; Mlecnik, E.; Almeida, M.; Barbosa, R.; Terés-Zubiaga, J.; et al. Building renovation at district level-Lessons learned from international case studies. Sustain. Cities Soc. 2021, 72, 103037. [CrossRef]

13. Ibarloza, A.; Malles, E.; Ibarloza, E.; Heras-Saizarbitoria, I. The needs and effects of housing renewal policies in Spain: Implications for sustainability and accessibility. Sustain. Cities Soc. 2018, 40, 244-253. [CrossRef]

14. Häkkinen, T.; Rekola, M.; Ala-Juusela, M.; Ruuska, A. Role of Municipal Steering in Sustainable Building and Refurbishment. Energy Procedia 2016, 96, 650-661. [CrossRef]

15. Paiho, S.; Ketomäki, J.; Kannari, L.; Häkkinen, T.; Shemeikka, J. A new procedure for assessing the energy-efficient refurbishment of buildings on district scale. Sustain. Cities Soc. 2019, 46, 101454. [CrossRef]

16. Martín-Consuegra, F.; de Frutos, F.; Oteiza, I.; Agustín, H.A. Use of cadastral data to assess urban scale building energy loss. Application to a deprived quarter in Madrid. Energy Build. 2018, 171, 50-63. [CrossRef]

17. D'Alonzo, V.; Novelli, A.; Vaccaro, R.; Vettorato, D.; Albatici, R.; Diamantini, C.; Zambelli, P. A bottom-up spatially explicit methodology to estimate the space heating demand of the building stock at regional scale. Energy Build. 2020, $206,109581$. [CrossRef]

18. Santamouris, M.; Kapsis, K.; Korres, D.; Livada, I.; Pavlou, C.; Assimakopoulos, M.N. On the relation between the energy and social characteristics of the residential sector. Energy Build. 2007, 39, 893-905. [CrossRef]

19. de Cos Guerra, O.; Usobiaga Ferrer, E. Methodological challenges to study demographic and residential deprivation on an intraurbano level to face changes on common statistical sources I Retos metodológicos para estudiar la vulnerabilidad demográfica y residencial a nivel intraurbano ante los cambios en las Fuentes estadísticas habituales. Scripta Nova 2019, 23. [CrossRef]

20. OECD. Integrating Distressed Urban Areas; OECD Publishing: Paris, France, 1998. [CrossRef]

21. Ministerio de Transportes, Movilidad y Agenda Urbana. Observatorio de la Vulnerabilidad Urbana. 2021. Available online: https://www.mitma.gob.es/arquitectura-vivienda-y-suelo/urbanismo-y-politica-de-suelo/observatorio-de-lavulnerabilidad-urbana (accessed on 13 December 2021).

22. Rodríguez Suárez, I.; Hernández Aja, A.; Gómez Giménez, J.M.; Matesanz Parellada, Á.; Díez Bermejo, A. Los Catálogos de Barrios Vulnerables de España. Análisis de la vulnerabilidad en las ciudades españolas entre 1991 y 2011. Ciudad y Territorio Estudios Territoriales 2021, vol. LIII (2021 MONO), 179-200. [CrossRef]

23. Ministerio de Transportes, Movilidad y Agenda Urbana. Atlas de la Edificación Residencial en España 2001-2011. 2021. Available online: http:/ / atlasedificacion.fomento.es/\#c=home (accessed on 13 December 2021).

24. De Santiago-Rodríguez, E. La Estrategia de Rehabilitación ERESEE 2020: Una oportunidad para un cambio de modelo en el sector de la vivienda en España. Ciudad y Territorio Estudios Territoriales 2021, 53 (2021 MONO), 239-276. [CrossRef]

25. Molina-Costa, P. Las Estrategias Locales de Regeneración y Rehabilitación y su potencial para el impulso de las actuaciones de rehabilitación con criterios de eficiencia energética. In Innovaciones Recientes en España en Materia de Rehabilitación y Regeneración Urbana; Estudio (08) para la ERESEE 2020 “Estrategia a largo plazo para la Rehabilitación Energética en el Sector de la Edificación en España"; Ministerio de Fomento: Madrid, Spain, 2019; pp. 47-62. Available online: https:/ / cdn.mitma.gob.es / portal-webdrupal/planes_estartegicos/8_2020_innovaciones_sobre_rehabilitacion_anexo_i.pdf (accessed on 13 December 2021).

26. Fundación Tecnalia Research \& Innovation, GIAU+S-UPM and caviar-UPV. Diagnóstico de las Necesidades de Intervención en la Renovación del Parque Edificado de la CAPV. Departamento de Vivienda, Obras Públicas y Transportes, Gobierno Vasco, 2011. Available online: https:/ / www.etxebide.euskadi.eus/x39-ovad03/es/contenidos/informacion/ovv_direcc_vivienda/es_ovv_ sevi/ovv_sectorvivienda245_es.html (accessed on 13 December 2021).

27. Consejería de Fomento y Medio Ambiente, Junta de Castilla y León. Estrategia de Regeneración Urbana en Castilla y León (ERUrCyL). 2016. Available online: http:/ /www.jcyl.es/junta/cma/ERUCyL.pdf (accessed on 13 December 2021). 
28. Serrano Lanzarote, B.; García Prieto Ruiz, A.; de los Ríos Rúperez, I.; Soto Francés, L.; Temes Cordovez, R.; Gil Vila, M.; Azara Escrivá, S.; Hervás Más, J.; Rodriguez Contreras, C.; de Leon, Y. Directrices Para el Desarrollo de Estrategias de Regeneración Urbana Para Municipios de la Comunitat Valenciana. Instituto Valenciano de la Edificación, 2018. Available online: http: / / www.habitatge. gva.es/es/web/vivienda-y-calidad-en-la-edificacion/estrategia-de-regeneracion-urbana-de-la-comunitat-valenciana (accessed on 13 December 2021).

29. Ruiz Palomeque, G.; Rubio del Val, J. Estudios y Propuestas para la Rehabilitación de 21 Conjuntos Urbanos de Interés. Zaragoza Vivienda, 2006. Available online: http:/ / oa.upm.es/14586/2/Nuevas_Propuestas_de_Rehabilitacion_Urbana_de_Zaragoza_3. pdf (accessed on 13 December 2021).

30. Foment de Ciutat, S.A. Estudi i Detecció a la Ciutat de Barcelona d'àmbits de Vulnerabilitat Residencial. 2017. Available online: https:// bcnroc.ajuntament.barcelona.cat/jspui/handle/11703/102699 (accessed on 13 December 2021).

31. Villacañas Beades, S.; Vila, G.; Moix, M.; Vima, S.; Balcells, A.; Amela, J. MADRID RECUPERA Estrategia de Regeneración Urbana. Dirección General de Planificación Estratégica, Área de Gobierno de Desarrollo Urbano Sostenible, Ayuntamiento de Madrid, 2016. Available online: https:/ / planmadre.madrid.es/ (accessed on 13 December 2021).

32. Andrés Mateo, C.; Masiá González, L. Plan Especial de Reforma Interior Para la Planificación de Actuaciones de Rehabilitación, Regeneración y Renovación Urbana, en el Municipio de Palencia. Avance; Ayuntamiento de Palencia: Palencia, Spain, 2018.

33. Molina-Costa, P. Methodology for Demarcation of Priority Areas for Integrated Urban Regeneration. In Proceedings of the BIA Urban Regeneration Forum 2014, Bilbao, Spain, 24-26 September 2014.

34. Fundación Tecnalia Research \& Innovation; Ekoiure Abogados; MaaB Arquitecura y Urbanismo; Fincas Ezkurdi. Ecoinnovación en Regeneración Urbana: Guía Metodológica Para la Regeneración Urbana Integrada de los Barrios de la CAPV Construidos en 1950-1970; Ihobe: Bilbao, Spain, 2018.

35. Rubio del Val, J.; Molina Costa, P. Estrategias, retos y oportunidades en la rehabilitación de los polígonos de vivienda construidos en España entre 1940 y 1980. Ciudades 2017, 13, 15-37. [CrossRef] 